\title{
The Witch Hazel Family (Hamamelidaceae)
}

by Richard E. WeAver, JR.

The Arnold Arboretum has claimed that there is a tree or shrub in bloom every month of the year on its grounds in Jamaica Plain, Mass. In many years this assertion is true, but only because of a single genus of plants, Hamamelis, the Witch Hazels. As December arrives, the last pale yellow flowers begin to fade on the Common Witch Hazel, $H$. virginiana, a native of the eastern United States. And with the New Year come the fragrant, bronzy flowers of the Vernal Witch Hazel, $H$. vernalis, closely followed by the bright and beautiful yellow blossoms of the Chinese species, H. mollis.

The Witch Hazels belong to the Hamamelidaceae, a family of plants which are mostly neglected by the American horticultural public. Admittedly, the family is insignificant horticulturally compared with some others, for example, the Rose Family, as a result of the diversity and sheer number of its genera and species, and the Magnolia Family, because of the universal appeal of some of its members. But a high percentage of the species in the Hamamelidaceae are first class ornamentals, possessing charm, beautiful and often fragrant flowers, unusual blooming times, and brilliant autumnal coloration. Most also are easy to grow if the soil is light and loamy, and they bloom reasonably well in partial shade. In addition, they are not bothered by any serious diseases or insect pests.

This article will present a brief discussion of all of the genera which are hardy in the northern half of the United States. Keys are provided for the identification of genera and species. The references listed are those which were consulted in the preparation of the article, and they are recommended for anyone desiring further information. Many of the species are rarely encountered in the American nursery trade, so sources are given if they exist. Nurseries are listed by name for each species and cultivar, with the addresses at the end of the article. Some, however, may not be current. For those willing to import plants from abroad, Hilliers' Nursery in Ampfield, Hampshire, England, lists all of the species treated here. I am most grateful to Mrs. Ida Burch, of the Arnold Arboretum staff, for preparing the list of the cultivars for the species treated here, for 

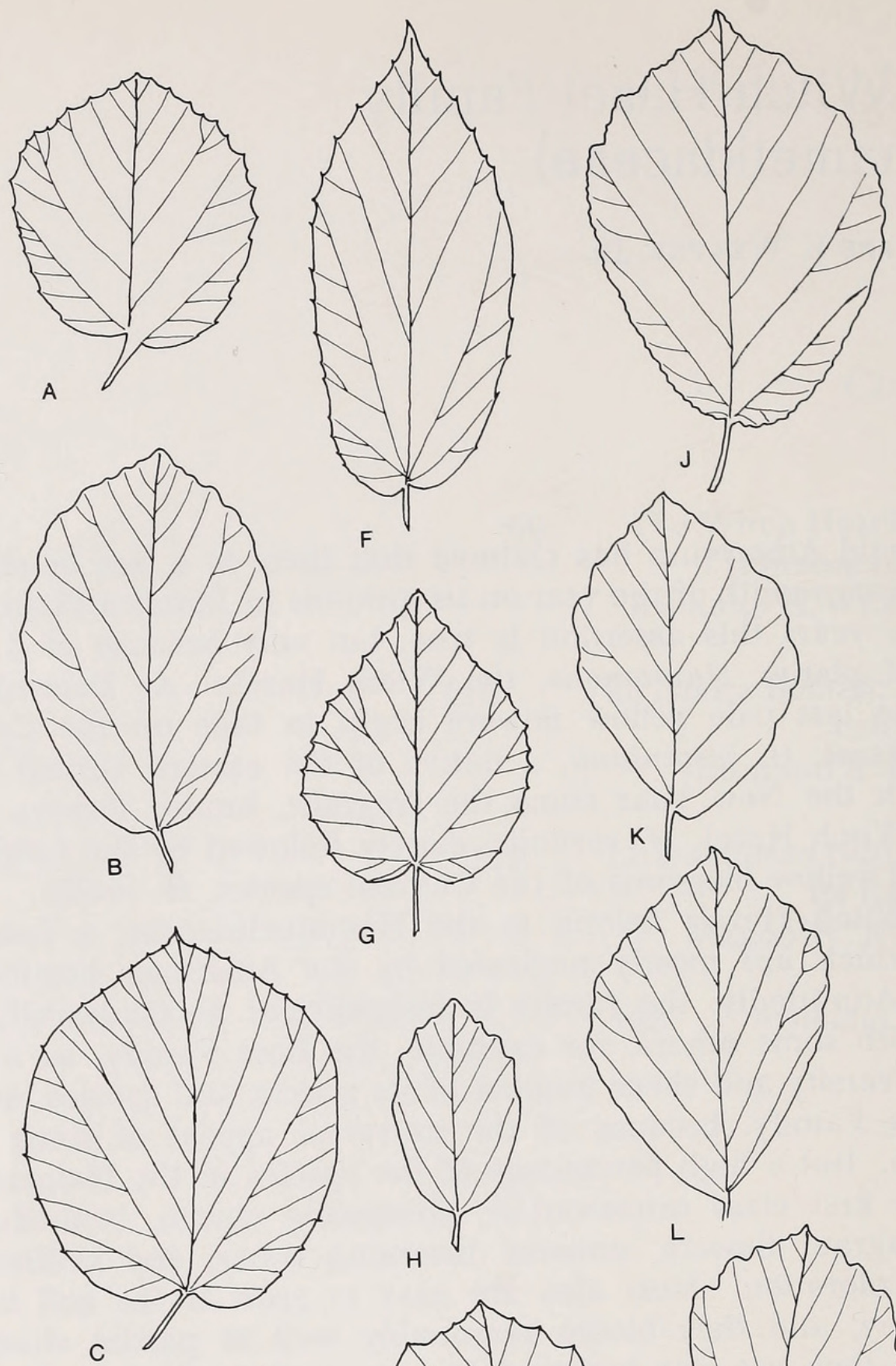

G
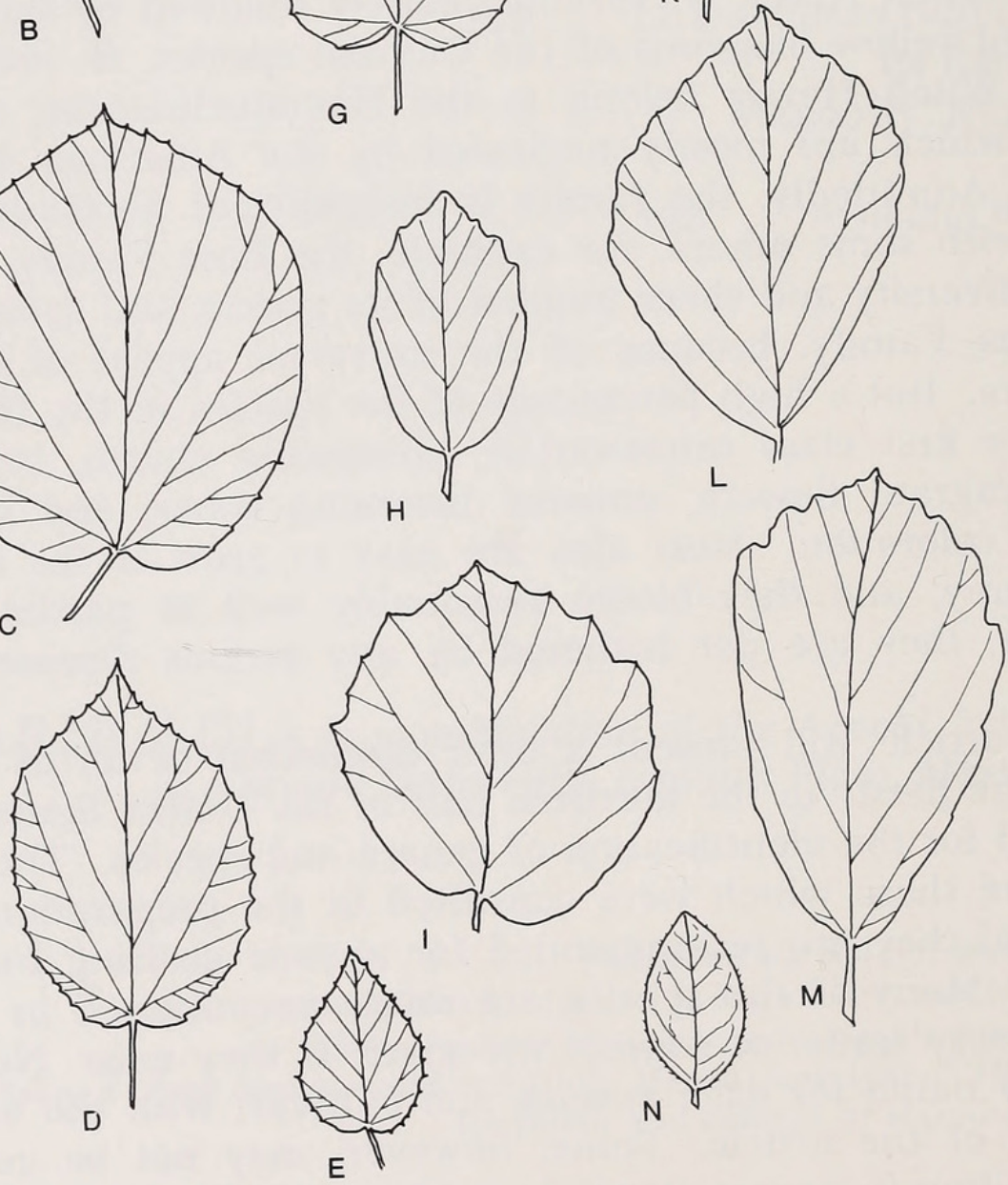

Leaves of the Witch Hazel Family - 1/3 life-size. A, Parrotiopsis jacquemontiana; B, Parrotia persica; C, Corylopsis spicata; D, C. platypetala; E, C. pauciflora; F, C. veitchiana; $G$, C. glabrescens; $H$, Fothergilla gardenii; I, F. major; $J$, Hamamelis mollis; $K, H$. virginiana; $L, H$. japonica; $M, H$. vernalis; $N$, Loropetalum chinense. 


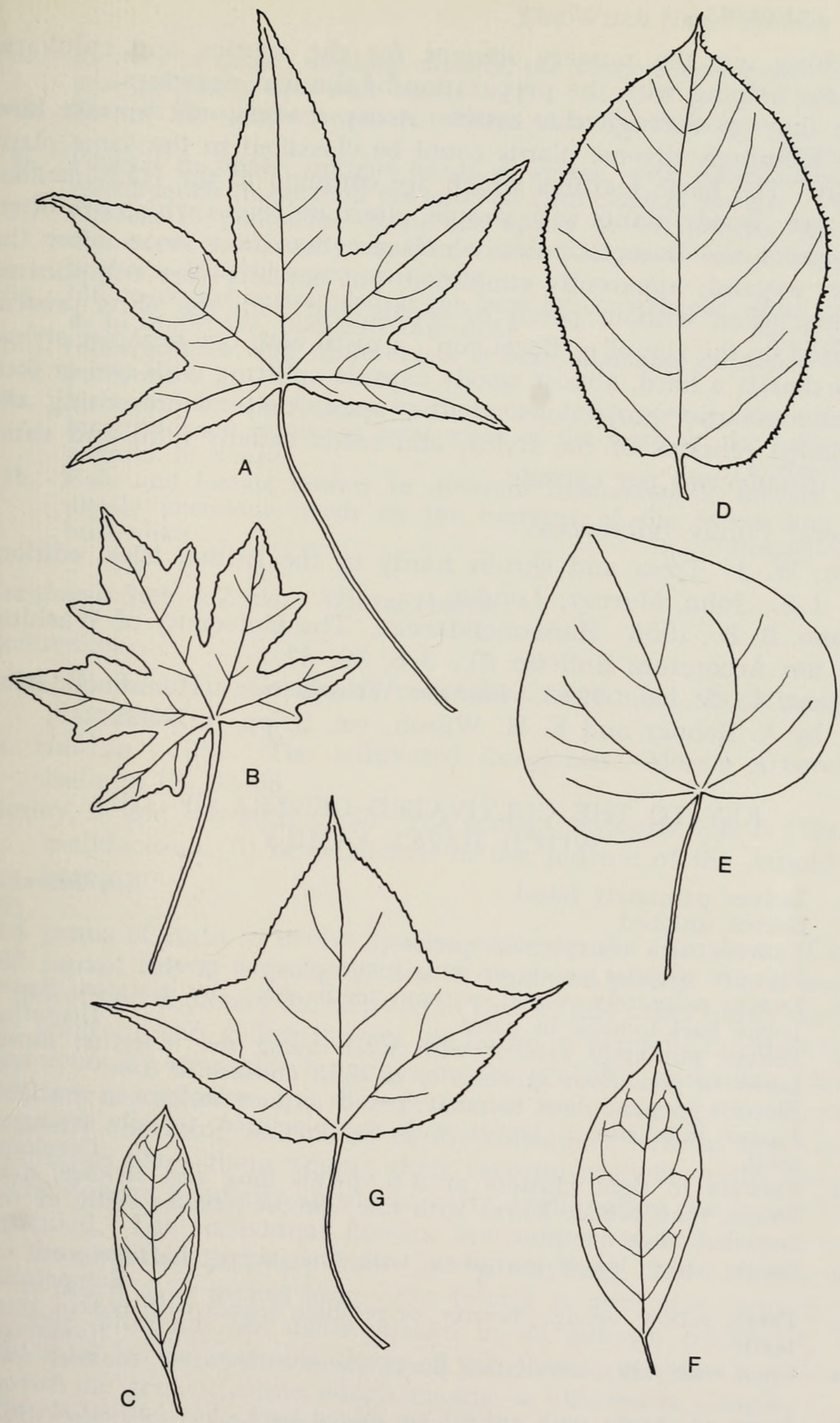

Leaves of the Witch Hazel Family - 1/2 life-size. A, Liquidambar styraciflua; $B$, L. orientalis; $C$, Distylium racemosum; $D$, Sinowilsonia henryi; $E$, Disanthus cercidifolius; $F$, Sycopsis sinensis; $G$, Liquidambar formosana. 
searching out the nursery sources for the species and cultivars, and for helping with the preparation of the leaf drawings.

As they go through this article, many readers will wonder how such seemingly diverse plants could be classified in the same plant family. The basic features which are common to the Hamamelidaceae are: woody plants with simple, alternate leaves which are often uneven at the base; stipules which are deciduous soon after the leaves expand; apparently simplified, but actually very complicated flowers, often without petals or sepals, but with the parts present inserted on the rim of a "floral cup"; a pistil with two separate styles; fruit that is a hard, almost woody capsule splitting with two or four usually slender projections at the apex, these representing the hardened remains of the styles; and seeds usually hard and shiny and usually two per capsule.

General family references:

Bean, W. J. Trees and shrubs hardy in the British Isles, editions 1-8. John Murray, London.

Malmo, B. B. 1958. Hamamelidaceae. The University of Washington Arboretum Bulletin 21: 3-6, 30, 31.

Sargent, C. S., ed. 1913. Plantae Wilsonianae. Hamamelidaceae by A. Rehder and E. H. Wilson, vol. 2, pp. 421-432.

\section{KEY TO THE CULTIVATED GENERA OF THE WITCH HAZEL FAMILY}

1a. Leaves palmately lobed

Liquidambar.

1b. Leaves unlobed

(2).

2a. Flowers with conspicuous petals

(3).

2b. Flowers without petals or with inconspicuous ones

3a. Leaves palmately veined, without teeth along the margins; flowers borne back-to-back in pairs

Disanthus.

3b. Leaves pinnately veined, with teeth along the margins; flowers borne in pendulous racemes or in tight clusters of 3-6.

4a. Flowers in pendulous racemes; petals as long as broad, or slightly longer than broad; leaves with sharp-pointed, usually triangular teeth ........................................................... Corylopsis.

4b. Flowers in tight clusters of 3-6; petals long and slender, much longer than broad; leaves with fine, almost hairlike teeth, or with rounded ones

5a. Petals white; leaves evergreen, with fine, almost hairlike teeth

Loropetalum.

5b. Petals yellow, orange, bronzy, or reddish; leaves with coarse, round teeth

Hamamelis.

6a. Trees with flaky, exfoliating bark; leaves with coarse, rounded teeth.

Parrotia.

6b. Trees or shrubs with smooth or ridged bark (but not exfoliating); leaves without teeth along the margins or with sharp-pointed ones.

7a. Leaves evergreen, without teeth, or with a few inconspicuous, scattered ones above the middle

7b. Leaves deciduous, with conspicuous teeth along the margin 
8a. Flowers in dense, nodding clusters, the clusters surrounded at the base by fuzzy, brownish bracts

8 b. Flowers in upright racemes, without conspicuous bracts Sycopsis.

.................. Distylium.

9a. Flowers in dense, upright heads or spikes, with conspicuous filaments much longer than the anthers; fruit clusters upright .... (10).

9b. Flowers in pendulous catkin-like spikes or in racemes, the filaments not particularly conspicuous, and about the same length as anthers; fruit clusters pendulous

10a. Inflorescences surrounded at the base by conspicuous white bracts, as in Dogwoods; filaments threadlike

Parrotiopsis.

10b. Inflorescences with white bracts at base; filaments thickened in upper portion

Fothergilla.

11a. Male and female flowers in the same inflorescence; flowers with inconspicuous petals; at least some of the teeth on the leaves triangular in shape

Fortunearia.

11b. Male and female flowers in different inflorescences; flowers completely apetalous; teeth on the margins of the leaves fine and bristle-like

Sinowilsonia.

Corylopsis Sieb. \& Zucc. Winter Hazels

References:

Bean, W. J. 1910. Corylopsis veitchiana. Botanical Magazine 136: plate 8349.

Li, Hui-Lin. 1962. The cultivated Corylopsis. Morris Arboretum Bulletin 13: 63-68.

Morley, B. and Jew-Ming Chao. The genus Corylopsis S. \& Z. (Hamamelidaceae). To be published in the Journal of the Arnold Arboretum.

A genus of eight to twelve species native to the Himalayas, China and Japan, this is a group of fine ornamental plants. Their aspect in flower is completely different from that of any other hardy shrubs. The fragrant, soft yellow flowers are borne in pendent racemes from conspicuously zigzagged branches on the graceful, spreading plants. They are not splashy, and their fragrance is not strong, but they are distinctly charming and many of my colleagues here at the Arnold Arboretum place them among their favorite early-flowering shrubs.

The flowers generally appear in early April, before the leaves have expanded. The individual flowers are somewhat bell-shaped with five broad petals, and vary from $1 / 4$ to $1 / 2$ inch long. The racemes may be as much as 3 inches long. The foliage is attractive through the summer, although not distinguished in its autumn coloration; the individual leaves resemble those of the Hazels (Corylus), accounting for the generic name which means "a likeness to Corylus."

The species treated here are all hardy at the Arnold Arboretum, although most are planted in one of our most sheltered spots, the Center Street Area. They would not be recommended for a climate any more harsh than ours. Even here the buds are occasionally winter-killed, and the flowers themselves are sometimes nipped by 
spring frosts. Cultural requirements would be the same as for Witch Hazels - a good, rich soil and partial shade. They are most effective when planted in an informal situation, such as at the edge of woods or at the base of a large tree. The flowers will hold up well in water, and the form of the twigs and inflorescences are attractive in arrangements.

\section{KEY TO THE SPECIES OF CORYLOPSIS}

1a. Inflorescences (flower clusters) with 2-4 flowers; mature leaves usually less than 2 inches long

C. pauciflora.

1b. Inflorescences with more than 5 flowers; mature leaves usually more than 2 inches long

(2).

2a. Flowers greenish, small, individually $1 / 4$ inch long or less; flowerbearing winter buds slender, with a long tapering point; petioles (leaf stalks) usually with glandular hairs. .......... C. platypetala.

2b. Flowers yellow, larger, individually $3 / 8-1 / 2$ inch long; flower-bearing winter buds egg-shaped, blunt; petioles sometimes hairy, but the hairs not gland-tipped

3a. Leaf stalks and twigs with fine hairs

3b. Leaf stalks and twigs glabrous (without hairs)

4a. Inflorescences with less than 10 flowers

(5).

4b. Inflorescences with 11 or more flowers

C. spicata.

5a. Stalks and axis of inflorescences glabrous; anthers not protruding beyond the petals; capsules glabrous .................... C. glabrescens.

$5 \mathrm{~b}$. Stalks and axis of inflorescences pubescent; anthers protruding beyond the petals; capsule pubescent

C. veitchiana.

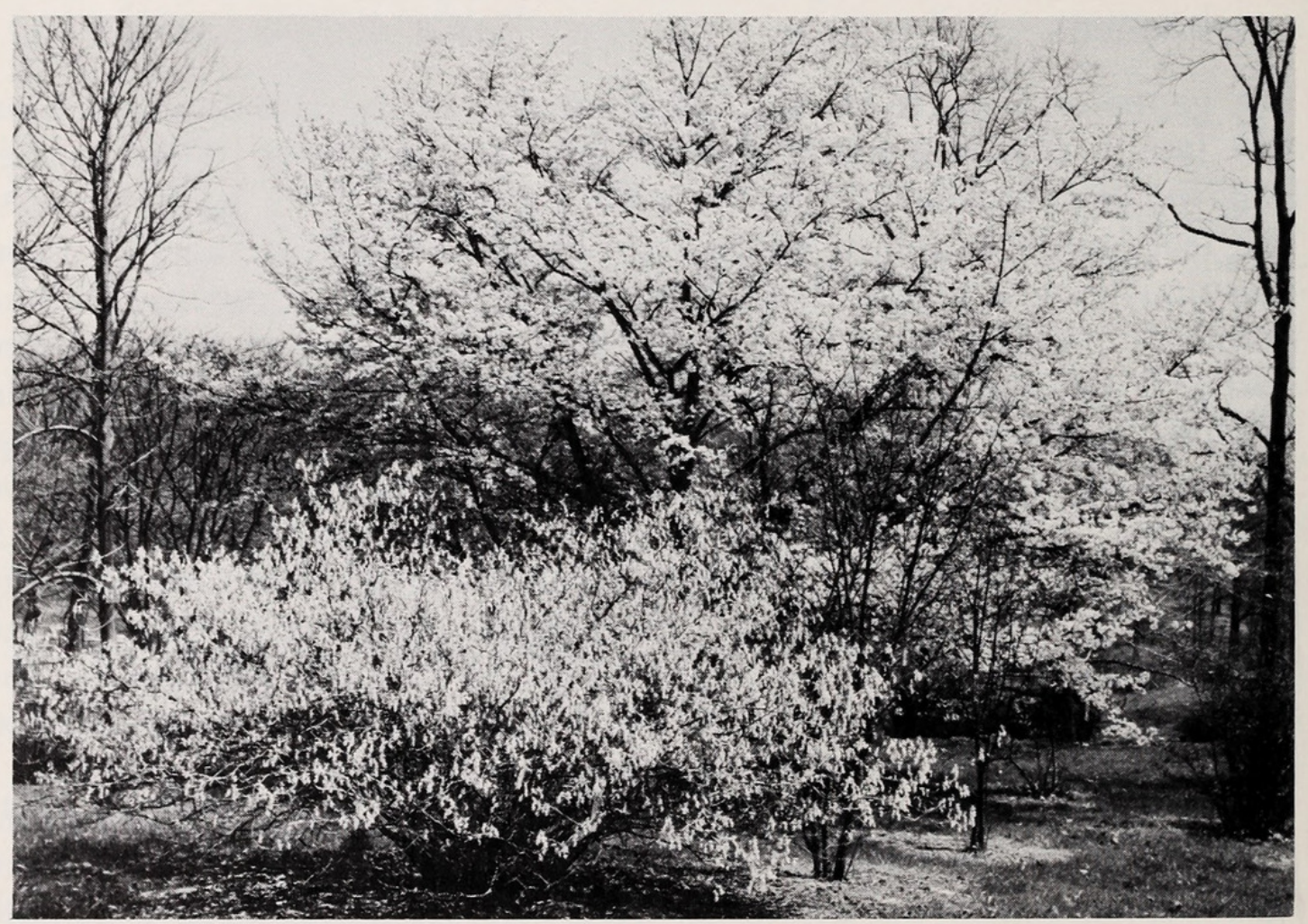

Corylopsis spicata in flower, with Prunus cyclamina in the background. Photo: H. Howard. 
Corylopsis glabrescens Fr. \& Sav.

\section{C. gotoana Makino}

A native of the mountains of Honshu and Kyushu, Japan, this species was introduced into cultivation from seeds collected by J. G. Jack for the Arnold Arboretum in 1905. It is one of the hardiest species, and at 4 to 6 feet, one of the lowest growing. The flowers are not as large as some of the other species, nor are they very fragrant. It is not commercially available in this country.

Corylopsis pauciflora Sieb. \& Zucc.

Although native to Taiwan, Korea, and the island of Honshu, Japan, most plants in cultivation are probably of Japanese origin. This species is reputedly not as hardy as some of the others, but in my experience it appears to be about the most reliable for bloom here at the Arnold Arboretum. The pale yellow flowers are in the shortest clusters of any species in the genus, but they are also the largest among those of the hardy species, and they open more fully than most others. Since they also appear in profusion, this is perhaps the showiest species. The plant grows to about 10 feet tall here in New England. It is available from the following nurseries: Gossler Farms, Gulfstream, Hollandia, Malmo, and Tingle.

Corylopsis platypetala Rehd. \& Wils.

This species, a native of western China, was discovered by E. H. Wilson, who introduced it into cultivation. One of the plants from the original seeds is still growing at the Arnold Arboretum. The species is not vigorous here, although in England it grows to be 20 feet tall. It is the latest blooming of the hardy species, and also the least showy. The racemes are long, but the flowers are small and yellow-green. The species is not commercially available in this country, and is rare even in botanic gardens. Most of the plants grown as this species appear to be either $C$. sinensis or C. veitchiana.

A close relative, and another Wilson introduction, C. wilmottiae Rehd. \& Wils., is apparently not grown in this country, and there seems to be much confusion about its identity in general. A cultivar (the only one in the genus) said to be of this species is offered by Hilliers'. It is called 'Spring Purple' because of the most attractive plum-purple color of the spring growth. As a parent in hybridization, this clone could give rise to some particularly attractive plants.

Corylopsis sinensis Hemsl.

Related to C. platypetala but more showy, this native of China was introduced by Wilson when he was collecting for Veitch and Son. It is somewhat tender here, and the only specimens at the Arnold Arboretum are still in the nursery. It is offered for sale by
Dauber and Gossler Farms. 
Corylopsis spicata Sieb. \& Zucc.

A native of Japan, this is the oldest species in cultivation. It is distinctive because of its non-flaring petals and its projecting red anthers. It is an attractive species, but forms a rather large plant. The largest specimen at the Arnold Arboretum is nearly 60 years old, and is 10 feet tall with a spread of 18 feet. A hybrid between this species and C. pauciflora (the only one reported for the genus) is being grown at Winterthur and the Morris Arboretum. From photographs, it appears to be most handsome, and it points out the ornamental possibilities of hybrids between other species. Corylopsis spicata is available from Brimfield and Hollandia.

\section{Corylopsis veitchiana Bean}

Another Wilson introduction for Veitch and Son, this native of western China is a particularly desirable species. In bloom and habit it resembles Corylopsis spicata, but the flowers are more open and there are more of them per raceme. In good years it is an attractive plant indeed. It is available in this country only from Tingle Nursery.

\section{Disanthus cercidifolius Maxim.}

Reference:

Bean, W. J. 1917. Disanthus cercidifolius. Curtis Botanical Magazine 143: plate 8716 .

Although it certainly has ornamental attributes, this plant is probably more interesting than beautiful. The curious, faintly ill-smelling flowers somewhat resemble those of the Witch Hazels, but they are more star-shaped, with five tapering, dark red-purple petals rather than four strap-shaped, yellow or reddish ones. They appear in the autumn as the leaves are falling, when few other shrubs are in bloom, but although individually attractive, they are seldom sufficiently profuse to provide much of a show.

The flowers are borne in a most unusual manner - in pairs, backto-back, on a short stalk - thus obviously accounting for the derivation of the generic name from the Greek dis, meaning "twice," and anthos, meaning "flower." The specific name meaning "leaves of Cercis," the Redbud genus, alludes to a resemblance that has nothing to do with evolutionary relationships, Cercis belonging to the Legume Family. The leaves of the two are remarkably similar; but they are completely different from those of all of the other plants in the Witch Hazel Family. In fact, Disanthus, with D. cercidifolius the only species, is usually classified as a distinct subfamily of the Hamamelidaceae.

Inflorescences of Corylopsis - Life-size. Upper left, C. veitchiana; upper right, C. spicata; below, C. pauciflora. Photos: P. Chvany. 
In the autumn the foliage of Disanthus turns a spectacular blend of reds, purples and oranges, even in the shaded position in which it seems to grow best. This along with its unusual flowers and elegant, spreading form would recommend it for more frequent cultivation.

The plant is native to the islands of Shikoku and Honshu, Japan, and is apparently quite rare in the wild. We have not been able to keep it for more than a few years at the Arnold Arboretum; it is apparently hardy only in Zone 6 . The only material offered in this country is seed, available from Schumacher.

Distylium racemosum Sieb. \& Zucc.

Reference:

Airy Shaw, H. K. 1937. Distylium racemosum. Curtis Botanical Magazine 160: plate 9501.

Distylium is a genus of about eight species distributed through much of tropical and subtropical Asia, with extensions into the more temperate zones. This species, a native of Japan, Korea, and Taiwan, is the only one in cultivation in the West. It is more curious than ornamental. The evergreen leaves somewhat resemble those of our native Mountain Laurel (Kalmia latifolia), and the flowers are conspicuous only for their large red anthers. Although becoming a small tree in the wild, cultivated specimens form stiff shrubs seldom more than 6 feet tall. Rehder lists the plant as being hardy in Zone 7 , and it does survive in Washington, D.C. In this country it appears to be cultivated primarily in California, but no commercial sources have been located.

Fortunearia sinensis Rehd. \& Wils.

Another plant of little ornamental value and therefore rare in cultivation, Fortunearia sinensis, the only species, was discovered by Wilson in China and originally described by Rehder and Wilson at the Arnold Arboretum. It is named for Robert Fortune, another great student of the plants of China and Japan. Vegetatively this species resembles Sinowilsonia henryi, which will be discussed later. The flowers are in inconspicuous drooping racemes. Rehder gives its hardiness as Zone 5, but the original plants survived here for but a few years. It is probably no longer present in cultivation in this country.

Fothergilla L.

Reference :

Weaver, R. E., Jr. 1971. The Fothergillas. Arnoldia 31: 89-96.

The two known species of Fothergilla, occasionally called Witch Alders, are restricted in the wild to the southeastern United States. 


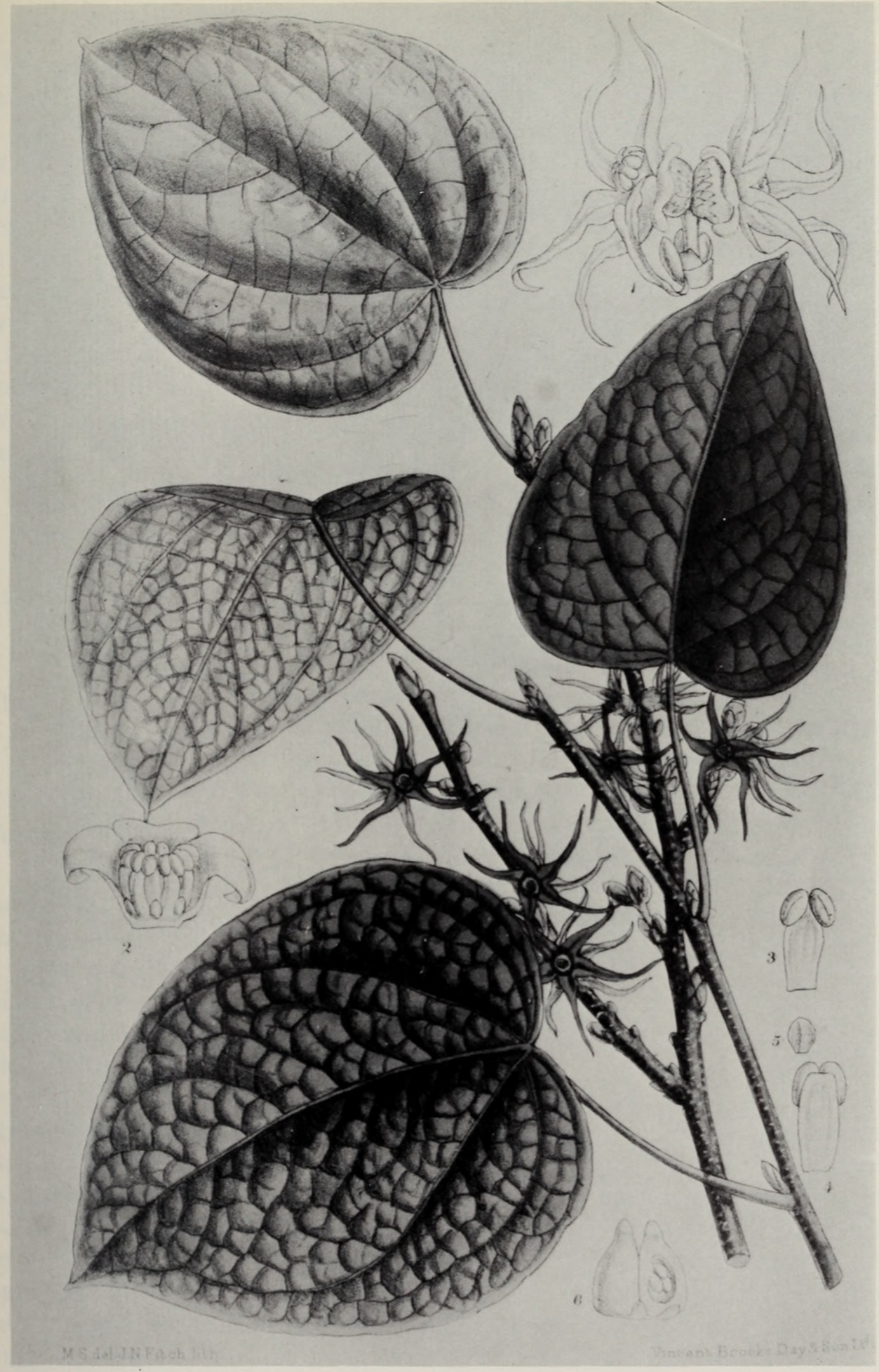

Disanthus cercidifolius, taken from Curtis Botanical Magazine, vol. 143, plate 8716. 


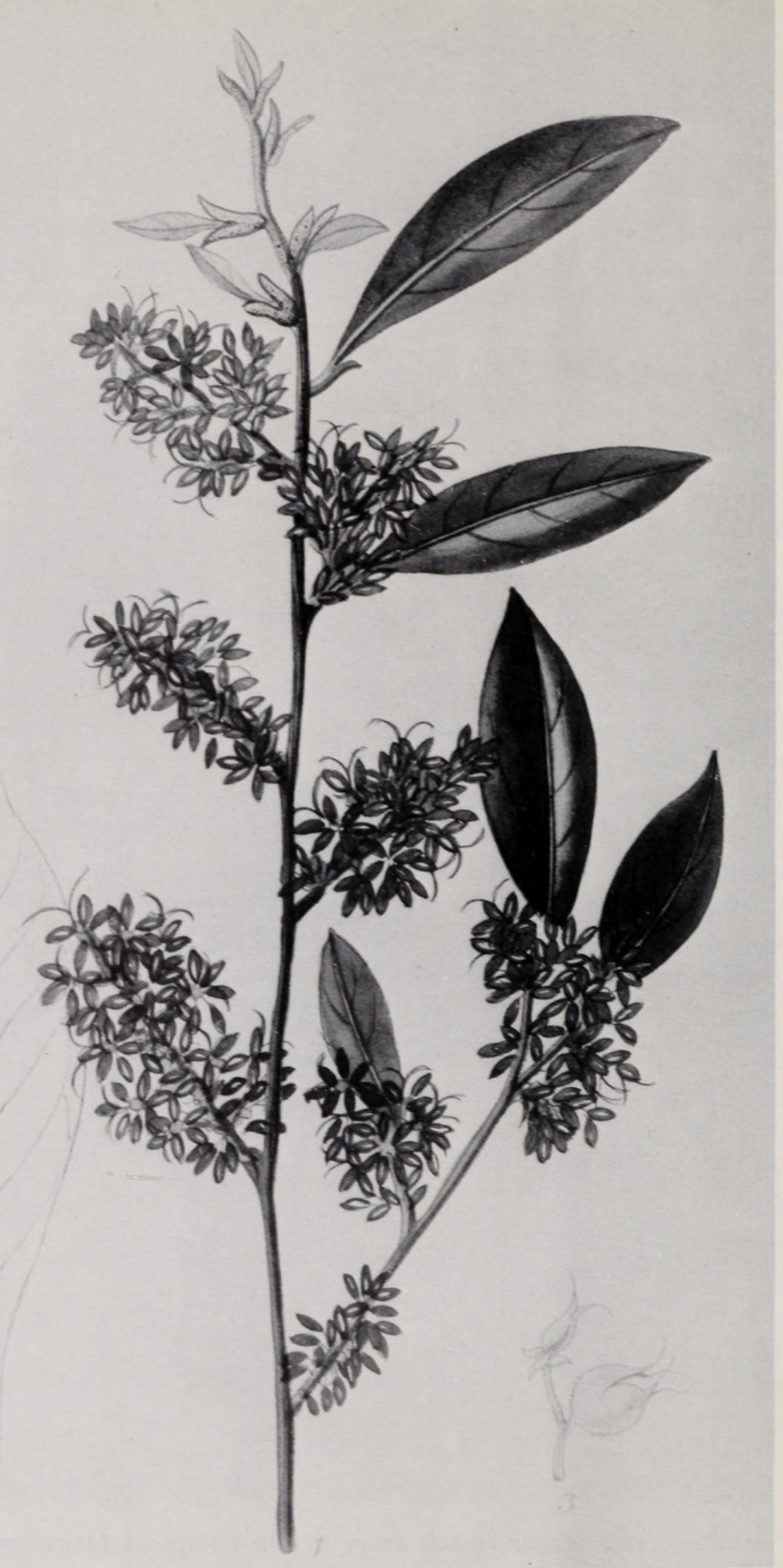

Distylium racemosum, taken from Curtis Botanical Magazine, vol. 160, plate 9501. 
They are quite similar in appearance except for stature, and they are among the more desirable ornamentals in the Witch Hazel Family.

The flowers lack petals, the conspicuous parts being the twelve to thirty-two long, creamy-white, narrowly club-shaped staminal filaments. The individual flowers are tiny, but they are massed together into a dense, upright spike resembling a "bottle-brush." The bloom is often profuse in cultivated specimens, so a plant in full flower is quite showy. The flowers are strongly scented, but the odor is of a type that is somewhat unpleasant to some people, myself excepted. Autumn coloration is spectacular, varying from red and orange in some specimens to mostly yellow in others. Bloom and autumn coloration are good even in partial shade, and both species grow well on poor, dry soils.

\section{KEY TO THE SPECIES OF FOTHERGILLA}

1a. Flowers appearing with the leaves; leaves usually more than 2 inches broad, the margins toothed to near the base; spikes usually more than 1/1/2 inches long; tall shrub, 3-10 feet tall at maturity

F. major.

1b. Flowers appearing before the leaves; leaves less than 2 inches broad, the margins toothed only above the middle; spikes less than $1 \frac{1}{2}$ inches long; low shrub, 11/2-3 feet tall at maturity

F. gardenii.

Fothergilla major Lodd.

This, the more ornamental of the two species, is native to the southern Appalachians where it typically grows on dry, sunny ridges. In the wild it is generally a straggling, stoloniferous shrub, attaining a maximum size of 20 feet. In cultivation it forms a more compact plant. Two growth forms are prevalent; one more or less erect, the other spreading. These have been considered to be two distinct species, Fothergilla major being the upright type, in addition to having leaves which are glaucous beneath, and $F$. monticola Ashe being spreading with leaves which are green on both surfaces. Intensive studies of wild populations have convinced me that $F$. monticola is not a valid species or even a variety. The plants observed in the wild are mostly of spreading habit, with both green- and glaucousleaved individuals growing side by side. Cultivated specimens are variable in other respects, including size of flowers and autumn coloration, but to date no clones have been selected and named as cultivars.

Fothergilla major blooms during the first half of May in New England, about the same time as the Redbuds, and the two planted together produce a most pleasing effect. The finest specimen at the Arnold Arboretum is planted just inside the Main Gate. This plant, 32 years old, is a shapely, rounded shrub 10 feet tall and about as broad. The species is perfectly hardy in Zone 5. It is available from 


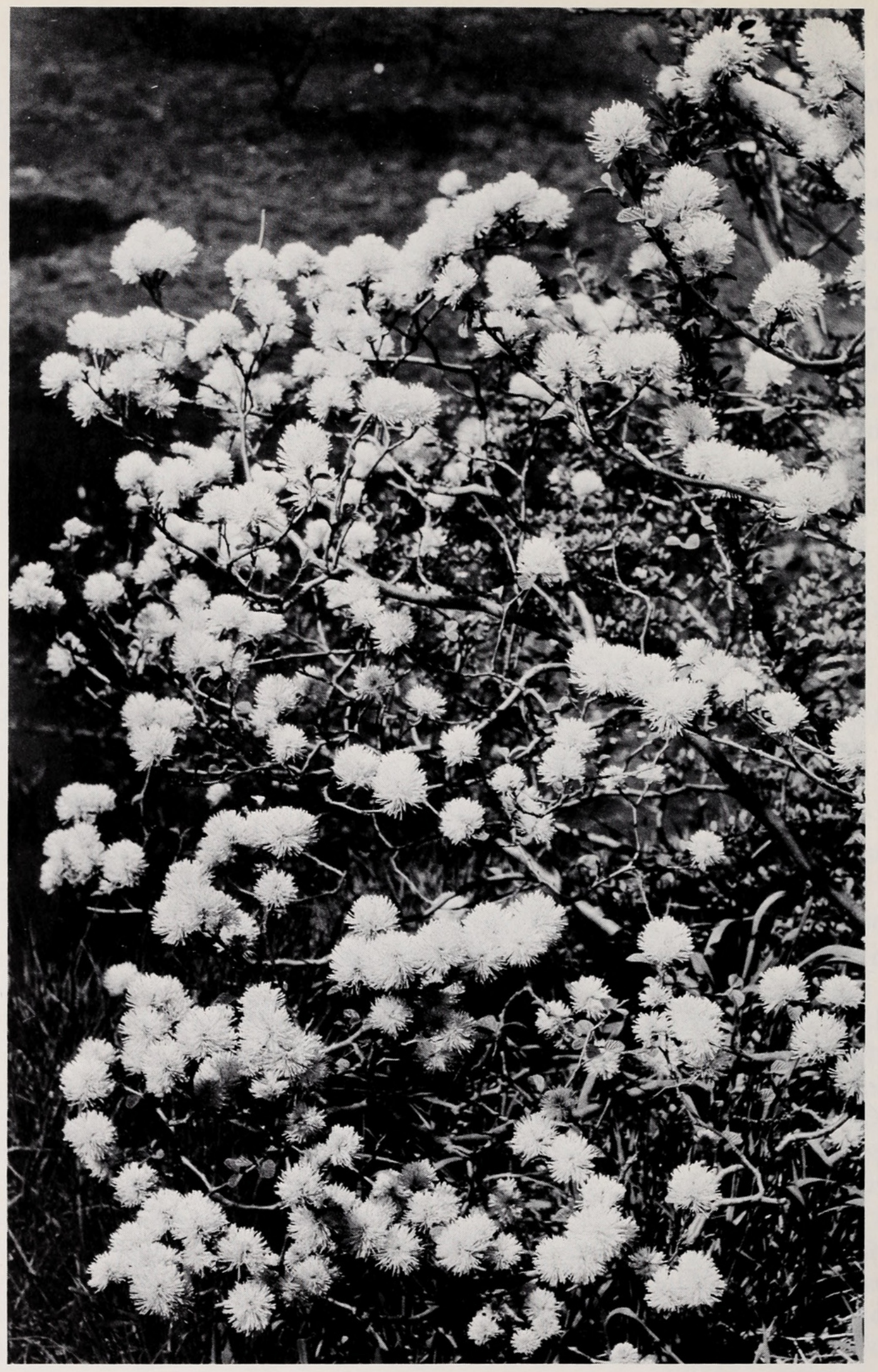

Above: Flowering branches of Fothergilla major. Photo: D. Wyman.

Right: Foliage and nearly mature capsules of Fothergilla major. Photo: $H$. Howard. 
the following nurseries: Brimfield, Charles Fiore, Hollandia, Gulfstream, Panfield, Princeton, Weston.

Fothergilla gardenii Murr.

F. alnifolia L.f.

F. parviflora Kearney

Native to the margins of swamps and pocosins on the Atlantic and Gulf Coastal Plains from Virginia to Alabama, Fothergilla gardenii is far less frequently cultivated than its more spectacular relative. Although it is generally less graceful in habit and may not bloom so profusely, it possesses most of the ornamental qualities of $F$. major, except on a smaller scale. In cultivation it is seldom more than 3 feet tall. It is slightly less hardy than F. major, and the Arnold Arboretum has lost the species a number of times. The plants presently in our collections are still quite young; they are best observed on Bussey Hill near the Dove Tree.

As in Fothergilla major, glaucous-leaved forms of F. gardenii occur in the wild. One of these has been given the cultivar name 'Glaucophylla', but it is doubtfully in the trade at present. The species is available only from Hollandia (as F. alnifolia), and from Gerard K. Klyn.

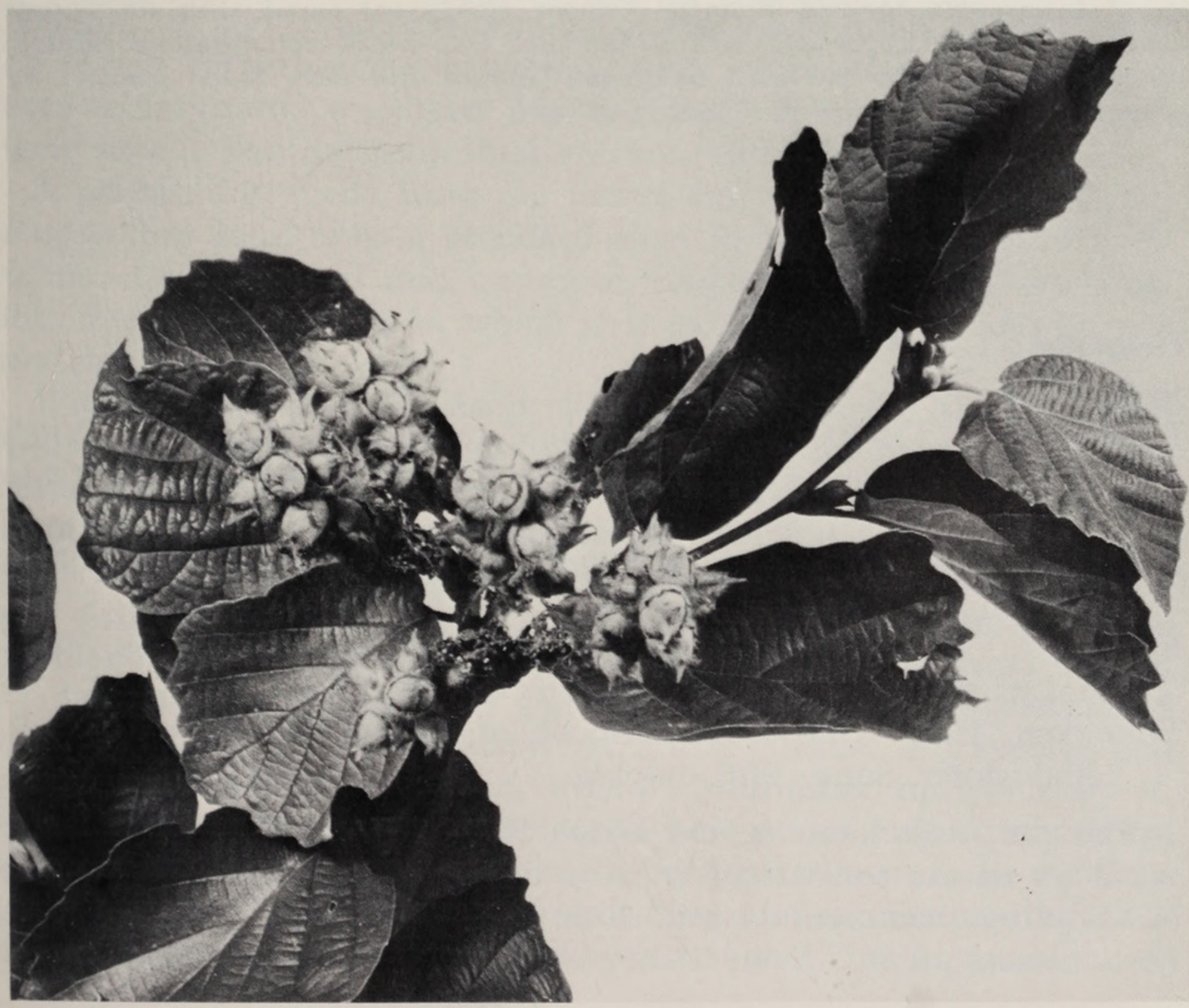




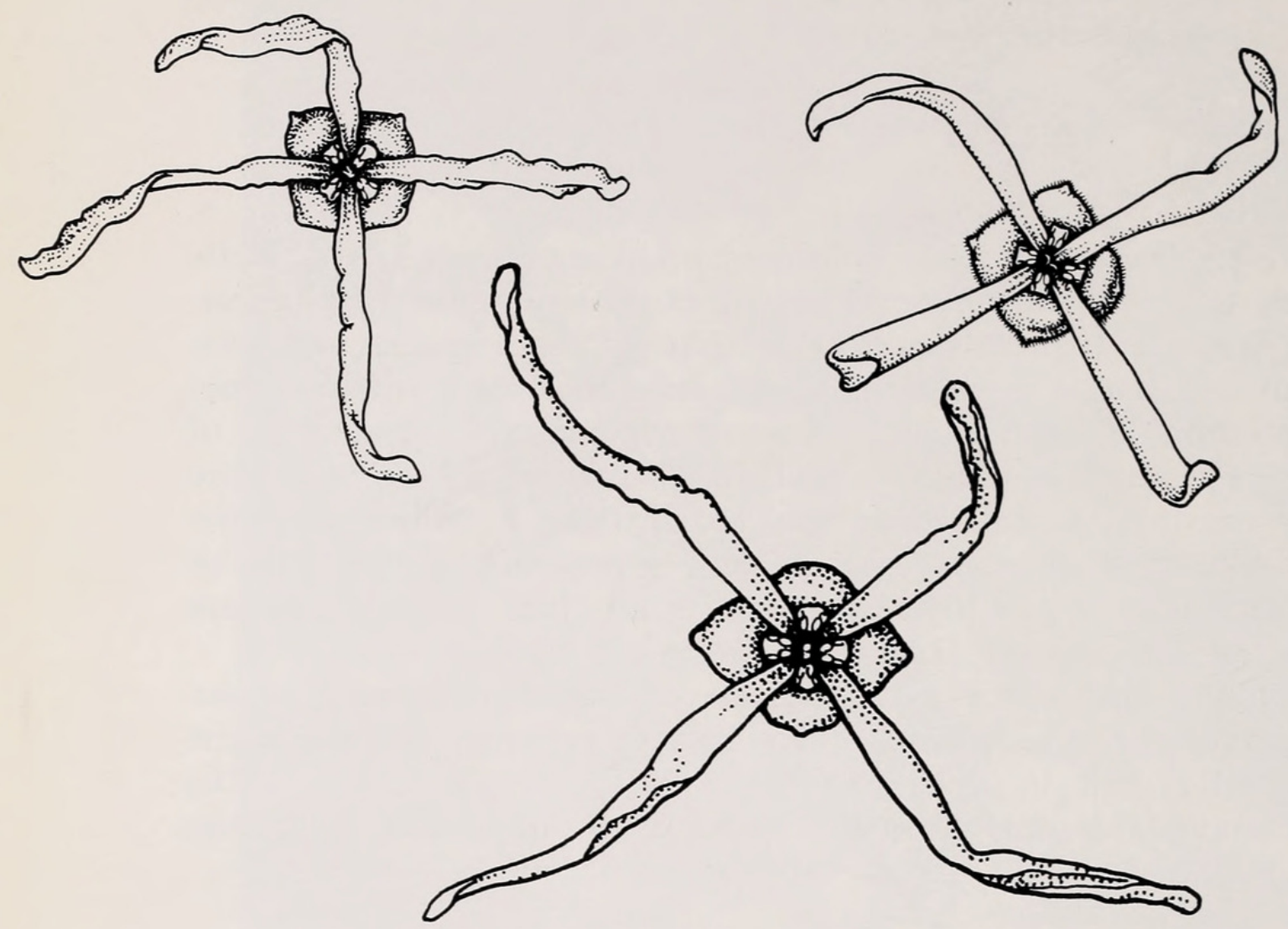

Flowers of Hamamelis (twice life-size), showing the intermediate nature of H. $\times$ intermedia 'Arnold Promise' (upper right) compared with its parent species $\mathrm{H}$. mollis (upper left) and $\mathrm{H}$. japonica (cv. 'Flavo-purpurascens' below). These drawings were prepared by Robin Lefberg and were made possible by a grant from the Stanley Smith Horticultural Trust.

\section{Hamamelis L. Witch Hazel}

\section{References:}

Lancaster, R. 1970. Complete guide to Hamamelis - the Witch Hazels. Gardeners Chronicle 167 (21) 32-35; (23) 26-29; (24) 24-27.

Peattie, D. C. 1966. A natural history of trees, ed. 2. Houghton Mifflin Co., Boston.

Rehder, A. 1945. Notes on some cultivated trees and shrubs. Journal of the Arnold Arboretum 26: 67-78.

Youngken, H. W. 1936. A textbook of pharmacognosy, ed. 4. P. Blakiston's Sons, Philadelphia.

The genus Hamamelis, the Witch Hazels, after which the family takes its name, consists of four or five species. Most of them are outstanding ornamentals still little appreciated by the American horticultural public. Even if they bloomed in the month of May, the 
height of the flowering season for woody plants in New England, they would be well worth growing for their visually delicate, fragrant, spidery flowers. But the fact that the various species bloom from September through March makes them indispensable for northern gardeners who want a year-round display from their flowering shrubs.

The flowers of Witch Hazels are borne in tight, usually outward or downward facing clusters of three to six. The four petals, yellow, orange, bronzy, or reddish, are long and strap-shaped and unfold in a most unusual manner - similar to the uncoiling of fern fiddleheads. It seems almost incredible that such delicate structures can withstand temperatures near $0^{\circ} \mathrm{F}$. without damage. But they do this quite well, coiling up on very cold days and uncoiling in milder weather. Equally incredible is the fact that the individual flowers remain fresh for 6 weeks or more. The four sepals are often colored a deep wine red on the inside, presenting a pleasing contrast to the paler petals. They persist after the petals have fallen and are then decorative in their own right. Autumn coloration of the foliage is an added ornamental feature, the color varying from bright yellow to shades of orange and red.

The name "Witch Hazel" is of uncertain origin. Almost certainly the last part is due to the resemblance of the leaves to those of Corylus, the true Hazels. But the "witch" probably has nothing to do with those unsavory characters who ride on brooms or were burned at the stake in Salem. It is probably derived from the word wych, meaning "to bend," applied because of the tough, limber branches of the plants. Whether the "witching rods," which doubtfully bend toward underground water, or "Witch Hazel," their traditional source, came first is like the proverbial chicken and egg.

A preparation made from the leaves and bark of Hamamelis virginiana has long been a standard item in barber shops and bathrooms. Its astringent and antiseptic properties, however, are probably due to the alcohol in which it is extracted, but it does have a nice smell.

Witch Hazels prefer a deep rich soil, and partial shade. Given these conditions they generally live and bloom for many years. The following discussion of the species and cultivars of Hamamelis will be brief because of the existence of an excellent article on the subject by Roy Lancaster (cited above), Curator of the Hillier Gardens and Arboretum, Ampfield, England. These plants are much more popular in Europe than here, and many of the fine cultivars are not available in this country. In general, the cultivars here mentioned are those that are in the American nursery trade. All species and cultivars are hardy in Zone 5 , with $H$. virginiana and probably $H$. vernalis also in Zone 4 . Our collection here at the Arnold Arboretum is somewhat scattered, but the main concentrations are in the Center Street Area and around the moist depression occupied by Leitneria floridana, between the Buckeyes and the Tree Legumes. 


\section{KEY TO THE SPECIES OF HAMAMELIS}

\section{1a. Plants blooming from September through December}

1b. Plants blooming from January through March

H. virginiana.

(2).

2a. Margins of the leaves with teeth to their base; leaves conspicuously hairy beneath into the summer, feeling soft and felty to the touch

2b. Margins of the leaves with teeth only in the upper two-thirds; leaves somewhat hairy beneath when unfolding, but soon becoming smooth

3a. Petals crinkled; flowers faintly fragrant

H. $\times$ intermedia.

3b. Petals not crinkled; flowers strongly fragrant H. mollis.

4a. Petals short, $1 / 4^{-3 / 8}$ inch long, not crinkled; densely branched shrub with strongly ascending branches

H. vernalis.

4b. Petals more than $1 / 2$ inch long, crinkled; shrub or small tree with spreading branches

H. japonica.

\section{Hamamelis $\times$ intermedia Rehd.}

This is not a species at all, but rather a hybrid between the Chinese Hamamelis mollis and the Japanese $H$. japonica. It was first described from seedlings raised at the Arnold Arboretum in 1929. Seeds had been collected the previous year from the specimens of $H$. mollis on the grounds. None of the resulting plants turned out to be true $H$. mollis, but rather were intermediate between this species and H. japonica, also present in the Arboretum collections. Several of these plants are still alive. Only one of them, the celebrated 'Arnold Promise', was propagated and registered as a cultivar.

The plants of Hamamelis $\times$ intermedia in our collection are large shrubs with several strongly ascending trunks. They begin to bloom in mid- to late February and remain in good condition until the middle of March. Several outstanding cultivars are described below.

'Arnold Promise' - In good years, the original plant of this cultivar is a joy to behold. It is planted to the side of the Administration Building, right outside the window by my desk, and it never fails to lift my spirits during the dark days of February. It is certainly the best Witch Hazel at the Arnold Arboretum. The flowers have stiffly drooping, bright yellow petals and sepals which are mahogany inside. Although produced in abundance, they are only faintly fragrant. The original plant, after 47 years, is 17 feet tall with a spread of 18 feet. The cultivar is available from the following nurseries: Carroll, Hess, Herman Losely, Panfield, Princeton, Weston.

'Jelena' - This cultivar was originally raised in Belgium. The flowers are large, and the petals yellow suffused with copper. Our plants are still small, but they are most attractive. According to Lancaster, the cultivars 'Copper Beauty' and 'Orange Beauty' are identical to this. It is available from Hollandia and West Oregon. 


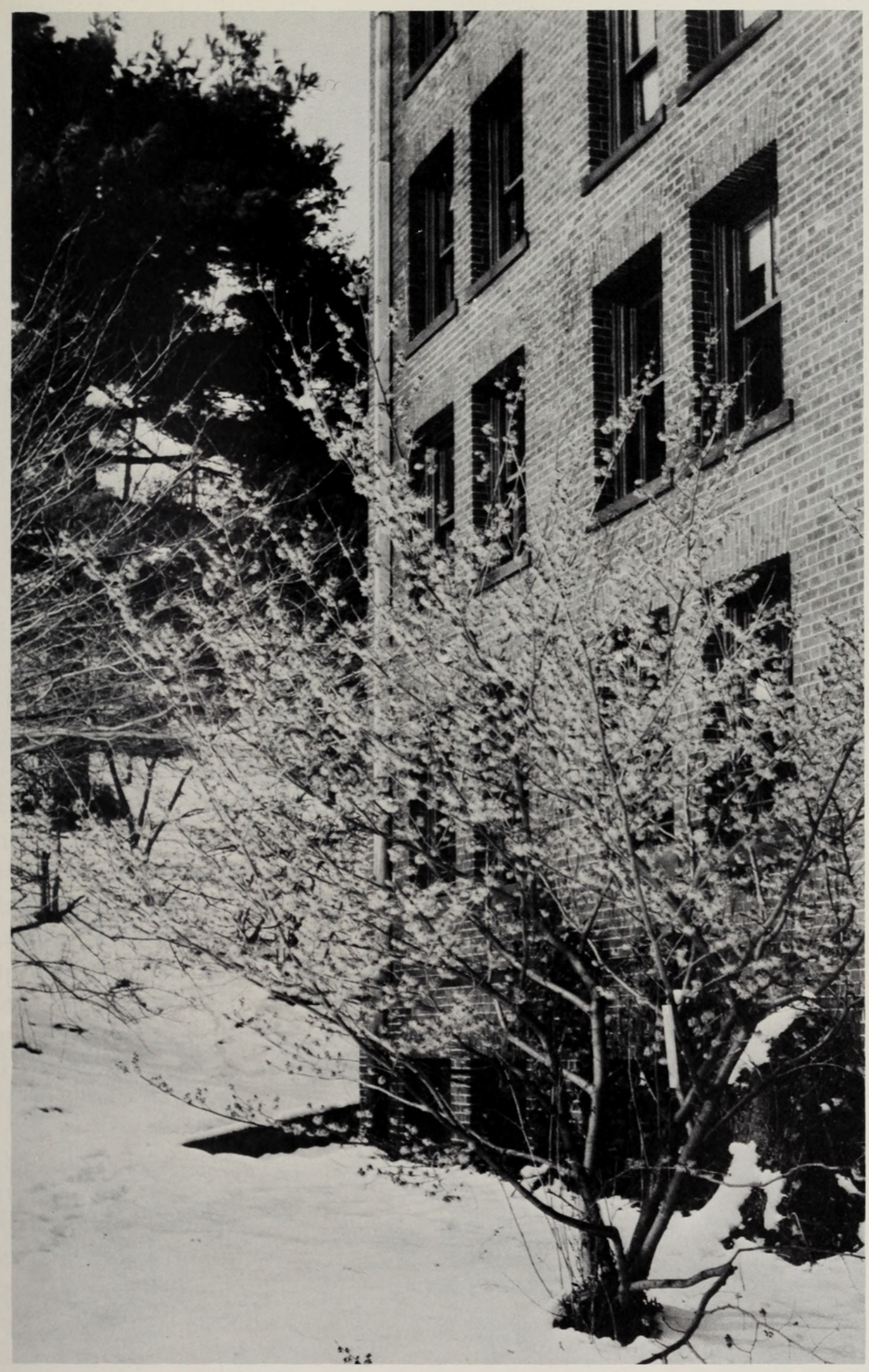

The original plant of Hamamelis 'Arnold Promise' beside the Administration Building at the Arnold Arboretum. As shown here, the flowers of this Februaryblooming plant are often covered with snow. 
'Ruby Glow' - Again of Belgian origin, this has the reddest flowers of any Witch Hazel available. The petals are medium red with a tinge of copper. It is often erroneously listed as a cultivar of Hamamelis japonica. It is available from the following nurseries: Charles Fiore, Hess, Hollandia, Tingle, West Oregon.

Hamamelis japonica Sieb. \& Zucc.

This native of Japan is generally a large shrub or small tree, but the cultivar 'Arborea' may reach a height of nearly 40 feet. The flowers appear in late February at the Arnold Arboretum; they are finished about the same time as those of the Hamamelis $\times$ intermedia cultivars and therefore do not lengthen the period of bloom for the genus. The flowers are large and spidery with narrow petals, those in the type of the species being bright yellow. Although some of the European cultivars are apparently quite beautiful, the plants offered in this country are inferior to the $H$. $\times$ intermedia cultivars. The species is offered by Charles Fiore, and the cultivar 'Rubra' (probably the same as 'Flavo-purpurascens') with yellow petals suffused with red at the base, is available from Tingle Nursery.

\section{Hamamelis mollis Oliv.}

A native of Central China, this species was first introduced by Charles Maries and was later also collected by E. H. Wilson. Several of our plants originate from Wilson's collections. Although in England plants of this species are often of ascending habit, the specimens at the Arnold Arboretum are widely spreading shrubs or small trees. The largest specimen, a sparse shrub with two main trunks, is 11 feet tall with a spread of 30 feet. The flowers appear here about the middle to the end of January, and individually are the handsomest in the genus, in my opinion. The sepals are mahogany inside and the petals are broad, bright yellow, and not crinkled. The flowers have a strong fragrance, so strong as to be almost overpowering when kept in a small room. Our specimens are never as floriferous as is 'Arnold Promise'.

Following are some of the cultivars which are available:

'Brevipetala' - The flowers of this plant have shorter petals than those of the species, but they are packed in dense clusters. It has the unfortunate attribute of holding its dead leaves into the winter, thus somewhat obscuring the flowers. The plant is available from: Brimfield, Weston, Tingle.

'Superba' - This is probably not a genuine cultivar, but rather a collection of selected clones of the species. It is available from Weston Nurseries.

Flowers of Witch Hazels - Twice life-size. Above: Hamamelis japonica 'Flavopurpurascens', a cultivar of the Japanese Witch Hazel with petals that are red at the base. Below: Hamamelis $X$ intermedia 'Jelena', a fine coppery-orange flowered plant. Photos: P. Chvany. 

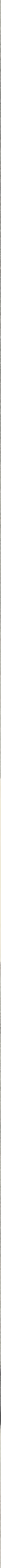


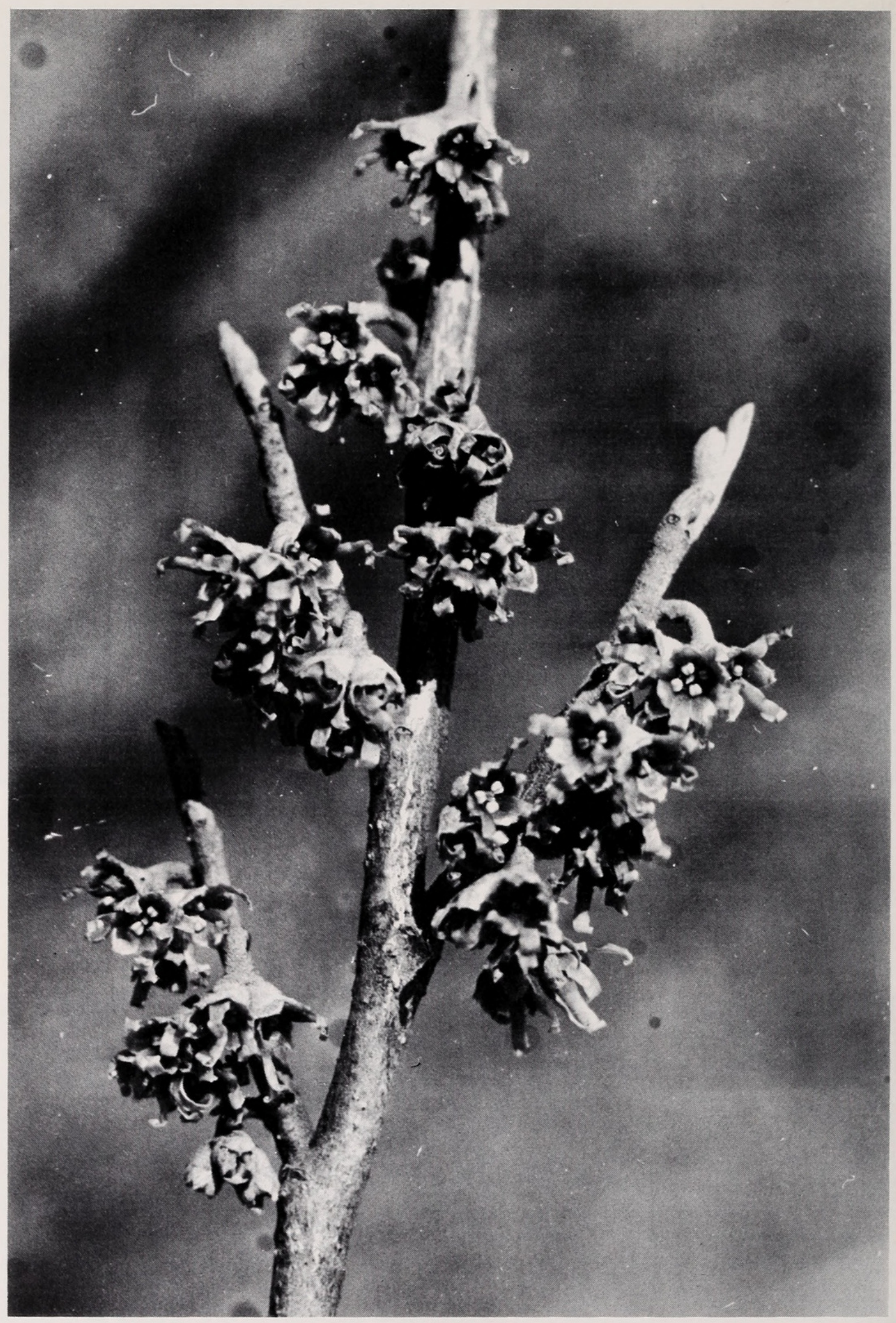

Flowering branch of Hamamelis vernalis, the Vernal or Ozark Witch Hazel (twice life-size). Photo: P. Chvany. 
'Pallida' - This is mentioned because it is supposedly one of the finest of all the Witch Hazels, as well as one of the most popular in Europe. The flowers are large, densely crowded, with bright yellow petals. It is not available in this country.

Hamamelis vernalis Sarg.

The Vernal or Ozark Witch Hazel is a native of the Ozark Mountains of Missouri, Arkansas and Oklahoma. It was originally described by Charles Sargent, the first Director of the Arnold Arboretum, and the type plant is still in our collections. This is the shrubbiest of the Witch Hazels, and also the one with the smallest flowers; unlike the others previously described, its autumn coloration is a clear yellow. The flowers, with short petals varying from pale orange to bronzy-red, are borne in great profusion and are strongly fragrant. They appear in January at the Arnold Arboretum, often during the first week of the month. Our mature specimens are immense; the 68-year-old plant by the parking lot of the Administration Building is a dense shrub 11 feet tall with a spread of 27 feet.

Alfred Rehder described a number of forms of this species, including $\mathrm{f}$. carnea, with dark reddish petals, and f. tomentella, with leaves pale and pubescent beneath. The latter is available in the trade, as "tomentosa," from Tingle Nursery.

The species is rarely cultivated, but is a desirable plant. Its large size should not be a problem since it is easily restrained. It is available from the following nurseries: Brimfield, Cole, Charles Fiore, Greenbriar, Gulfstream, Lake Co., Princeton, Panfield, Tingle.

Hamamelis virginiana $\mathrm{L}$.

This is the familiar Witch Hazel of eastern North America. It is a plant of the understory or the margin of forests from Canada to Georgia, and west to Nebraska. The pale yellow flowers open while the leaves are still green, and then are not conspicuous. As the leaves fall in October and November, the flowers become much more noticeable, and in good years this is a very attractive plant.

Plants in the wild are often sparse and straggling, but in cultivation form shapely large shrubs or small trees. At the Arnold Arboretum an old specimen, probably a spontaneous plant, is 20 feet tall with a spread of 34 feet. The largest of the numerous trunks is a foot in circumference.

A more southern plant with leaves that are more nearly lobed than toothed, and with flowers which appear in November, has been called a separate species, Hamamelis macrophylla Pursh. It is similar to $H$. virginiana in other respects, and is perhaps only a variety of that species.

Hamamelis virginiana is readily available in the trade. It is listed by the following nurseries: Charles Fiore, Cole, Forest, Greenbriar, Gulfstream, Herman Losely, Lake Co., Mellingers, Princeton, Panfield, Tingle. 


\section{Liquidambar L. Sweet Gum}

References :

Collins, W. H. 1964. New trees in the trade. American Nurseryman $120(3): 34$.

Peattie, D. C. 1966. A natural history of trees, ed. 2, Houghton Mifflin Co., Boston.

Santamour, F. S. 1972. Interspecific hybridization in Liquidambar. Forest Science 18: 23-26.

Ware, G. 1970. A sketch of the sweetgums. Morton Arboretum Quarterly 6 (1): 5-11.

Many readers will be surprised to find that this genus is a member of the Witch Hazel Family. With their palmately lobed leaves and fruits in spherical, spiny, pendent aggregates, the plants bear very little obvious resemblance to the Common Witch Hazel. A number of botanists are also skeptical about the inclusion of Liquidambar within the family. They would prefer to classify it and its close Asiatic relative in a separate family, the Altingiaceae. But detailed examination of the flowers and fruits of the Sweet Gums reveals many features basically similar to those of the other plants treated in this article. And Sweet Gum leaves are basically the same as those of Disanthus, except that they are lobed. But enough of taxonomy.

The genus Liquidambar consists of three species, widely separated geographically. All are handsome trees with maple-like leaves (but those of Maples are opposite) on long, slender petioles. The flowers appear with the leaves and are not decorative. They are borne in dense, spherical clusters, the "males" consisting almost entirely of stamens, in clusters of clusters, like an upright bunch of grapes. The "females" are usually in a solitary, drooping cluster.

The generic name, derived from the Latin liquidus, meaning "fluid," and the Arabic ambar, meaning "amber," alludes to the aromatic but bitter tasting gum which the trees exude. This substance has long been used by man, primarily as an incense or in perfumes, but also as a hopeful cure for a long series of ills. Historically derived from the Turkish species, Liquidambar orientalis, but present in the other species as well, the gum does appear to have some value as an expectorant and in the treatment of bronchial disorders. The aromatic principle is present in most parts of the plants, and the leaves and twigs are fragrant when crushed.

A magnificent specimen of Liquidambar formosana var. monticola growing wild in China. Photo: E. H. Wilson. 







\section{KEY TO THE SPECIES OF LIQUIDAMBAR}

1a. Mature leaves with 3 lobes; fruit aggregates with long bristles between the capsules, appearing and feeling bristly rather than spiny; winter buds densely silky-hairy

L. formosana.

1b. Mature leaves with 5-7 lobes; fruit aggregates without bristles, appearing and feeling spiny; winter buds not hairy, except on the margins of the scales

2a. Main lobes of the leaves with smaller lobes near the apex; branchlets without corky ridges

L. orientalis.

2b. Main lobes of the leaves without secondary lobes; branchlets usually with conspicuous corky ridges

L. styraciflua.

\section{Liquidambar formosana Hance}

A native tree through much of central and southern China, as well as the island of Taiwan and parts of Southeast Asia, this species is rare in cultivation in the United States except in California. According to Rehder and Wilson in Plantae Wilsonianae, mature trees in the wild often form majestic specimens as much as 125 feet tall with straight trunks and a much-branched crown. The leaves turn red or chestnut-brown in the autumn, and remain on the tree into the winter.

A variety, monticola, of this species, discovered by Wilson and introduced by him, differs little from the species except that its young growth is glabrous. However, plants grown from this Wilson material are considerably hardier than others of the species. They succeed very well as far north as Philadelphia, a very fine specimen being among the plantings of the Arthur Hoyt Scott Horticultural Foundation on the campus of Swarthmore College. Unfortunately, the plants from Wilson's collection survived on the grounds of the Arnold Arboretum for less than 10 years; the few subsequent trials have also met with failure. Plants of L. formosana are offered by Boething Treeland and Central Nursery Co.

\section{Liquidambar orientalis Mill.}

Even rarer in cultivation than the preceding species is this native of the mountains of Turkey. It is slow-growing in cultivation, usually forming a low, bushy tree. Rehder characterizes it as being hardy in Zone 6, and no specimen has lived for more than 9 years at the Arnold Arboretum.

\section{Liquidambar styraciflua L.}

The Sweet Gum is a native tree in the Ohio and Mississippi River valleys and in the Atlantic Coast states as far north as Long Island and western Connecticut. It typically is a plant of wet lowland forests where it reaches its greatest size. The largest specimen on record, in Richland Co., S.C. (American Forests, Jan. 1971), is 125 feet tall, its trunk more than 6 feet in diameter. However, in much 


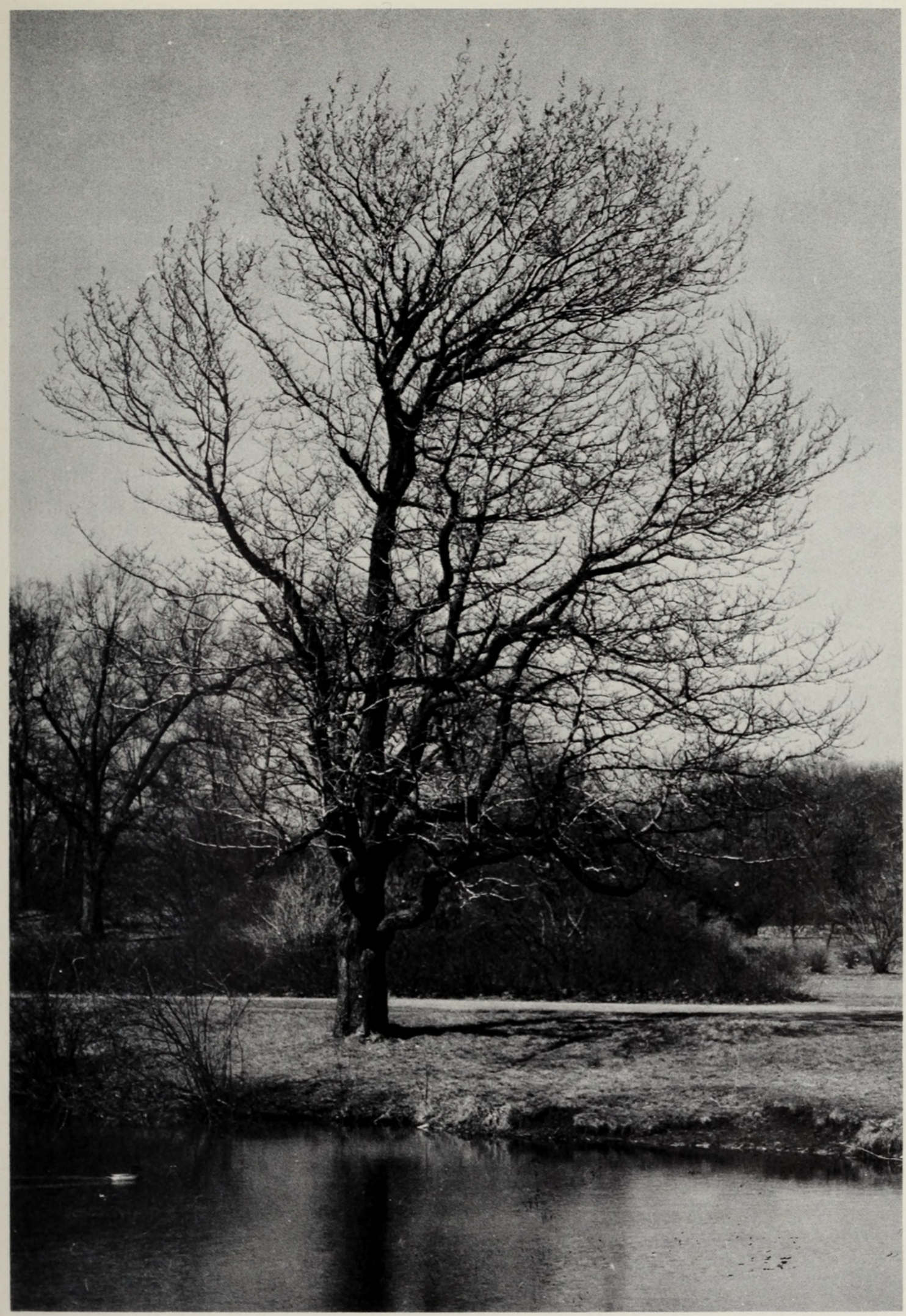

A mature specimen of the American Sweet Gum, Liquidambar styraciflua. Photo: H. Howard. 


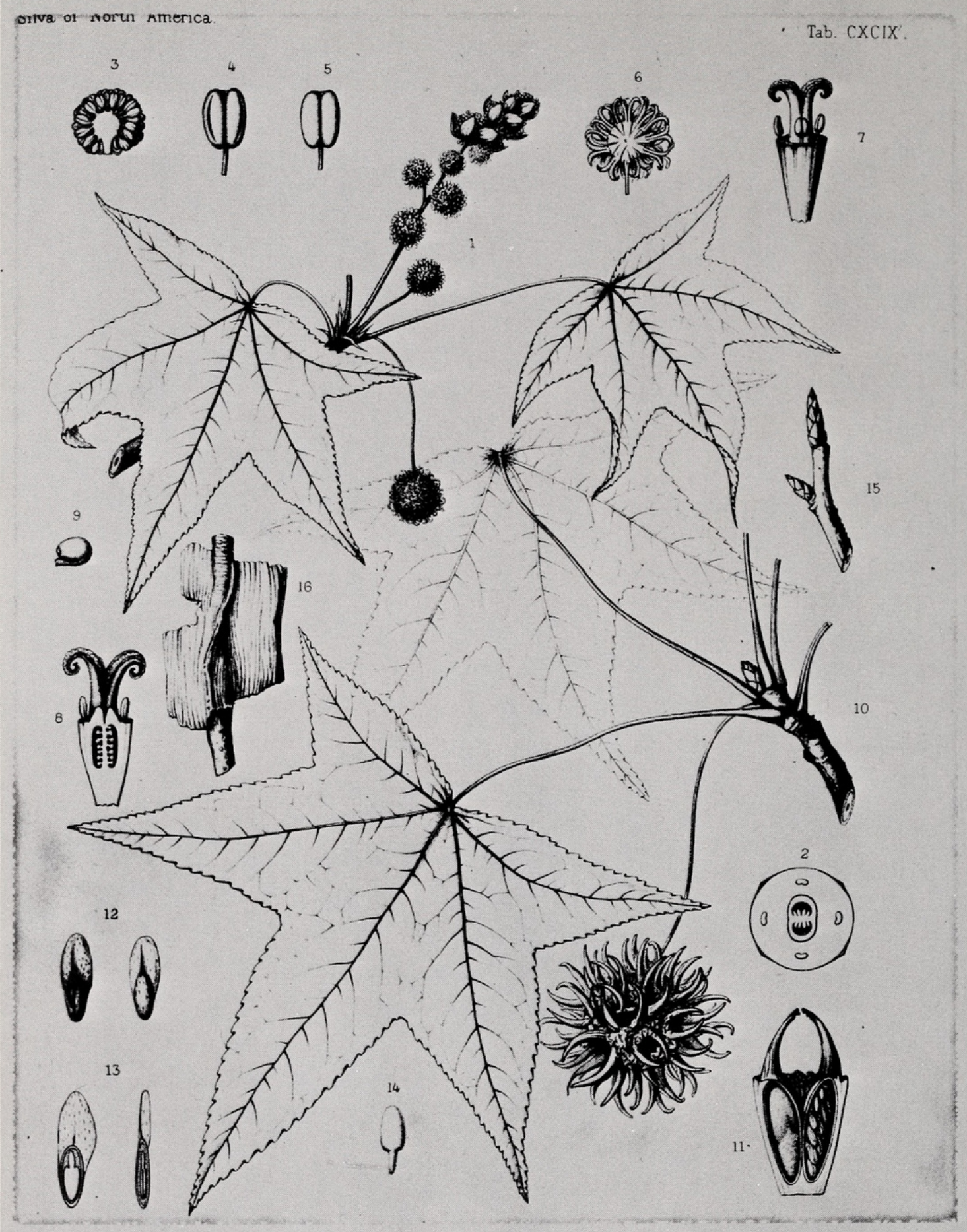

Detail of Liquidambar styraciflua. From Sargent, C. S. The Silva of North America, vol. 5, plate 199. Included are: flowering twig (1) with male inflorescences (upright), female inflorescence (pendent); cross-section of former (3); cross-section of latter (6); individual female flowers (7,8); seeds (12); corky ridges on twigs (16). 
of the Southeast, Sweet Gum is almost a weed tree, growing commonly along roadsides and in old fields. It is a handsome and desirable tree in cultivation. Most everything about it is attractive: its fragrant, glossy, star-shaped leaves; its spiny, globe-shaped fruit aggregates, remaining on the tree into the winter and a favorite component of "cone wreaths" and other winter decorations; its bark, silvery when young but dark and deeply furrowed with age; its twigs, with their curious, corky ridges; its form, symmetrical and pyramidal when young, but eventually with a tall, rounded crown; its ease of culture and its freedom from pests; and perhaps best, its autumnal coloration. This last feature varies from individual to individual sometimes a deep burgundy, sometimes a brighter red, but perhaps most commonly, a crazy-quilt pattern of colors from primrose to purple.

The Sweet Gum is one of a number of familiar plants of our eastern forests, including White pine (Pinus strobus) and Partridgeberry (Mitchella repens), which also occur in disjunct populations in the mountains of Mexico and Guatemala. I had forgotten that fact when, early in my graduate student days, I made a 3-month trip to Central America for course work and plant collecting. By the end of that summer I was anxious to get home, but I needed to stop in Mexico to collect a plant that was important to my research. I was also most anxious to see the great snow-covered volcanoes that lie on the eastern edge of the Valley of Mexico. Luckily, I had a collection locality near the base of one of these mountains, Citlaltépetl or the Pico de Orizaba. I arose early, and from my hotel window in the town of Orizaba I could see the very peak of the mountain over the buildings of the town. I caught a bus that I thought would take me close to my collecting site and the mountain. This time the mountain had priority, because tropical mountains have an annoying habit of covering themselves with clouds early in the day, not to reveal themselves again. I searched out a clearing in the forest, and there before me was the magnificent mountain, framed by, of all things, a Sweet Gum tree. One of my fondest memories to date is that morning - the Sweet Gum and the mountain, my feelings a mixture of awe, exhilaration, strangeness, familiarity and homesickness. But enough of nostalgia.

The Mexican Sweet Gums were the first of their species known to Europeans. The chronicler of Cortez' rape of the Aztecs reportedly recognized the smell of "liquidamber" in the tobacco which Montezuma offered the Spaniards (see the book by D.C. Peattie cited above).

The gum which is the source of "liquidamber" is still harvested from trees in the South and used as an aromatic in soaps, perfumes, and tobacco. According to Peattie, the bark of the trees is peeled off when the leaves have fully expanded. The gum gathers slowly and is scraped off, eventually to be heated and canned. 
The wood of the Sweet Gum has become very important in cabinetmaking. The heartwood, called Red Gum or Gumwood, has an attractive grain and a pinkish or ruddy color. All of the wood takes a high polish.

All in all, this plant is one of North America's finest trees. Several cultivars have recently been named. Short descriptions of these, with their commercial sources, follow.

'Aurea' - leaves striped and mottled with flecks of gold - Lake County Nursery.

'Burgundy' - at least in California, the leaves turning a uniform burgundy color later than other clones, and persisting on the tree into the winter - Cole, Monrovia.

'Festival' - fast growing, with an upright crown; leaves coloring yellow with tinges of peach - Cole, Monrovia.

'Gum Ball' - slow growing and bush-like - Forest Nursery.

'Palo Alto' - leaves changing simultaneously to a rich orange-red; tree with a uniform pyramidal crown - Cole, Lights, Monrovia, Peters \& Wilson.

'Pendula' - habit erect, but with pendent branches - source unknown.

'Rotundiloba' - lobes of leaves rounded rather than pointed; primarily a curiosity - source unknown.

'Variegata' - leaves broad, mottled with yellow - Hess, Scanlon.

Dr. Frank Santamour, of the U.S. National Arboretum, has produced hybrids between all three of the species. These have not been distributed, and their ornamental possibilities are not known.

\section{Loropetalum chinense Oliv.}

References:

Creech, J. L. 1960. On the distribution of Loropetalum chinense. American Horticultural Magazine 39: 236.

Helmsley, W. B. 1904. Loropetalum chinense. Curtis Botanical Magazine 130: plate 7979.

Wilson, E. H. 1911. Loropetalum chinense. Horticulture 14: 799.

This plant, which has been called the Chinese Fringe Shrub, is closely related to Hamamelis, and the flowers of the two are similar in shape, size, and arrangement. Those of Loropetalum, however, have white petals. The two genera are amply distinct in additional features, particularly the foliage. The leaves of Loropetalum chinense, the only species known, are usually less than 2 inches long; they have fine, almost hairlike teeth along the margins, and they are evergreen, at least south of Washington, D.C.

Forming a twiggy shrub with horizontal branches, and growing to about 8 feet tall in cultivation with fragrant flowers appearing 


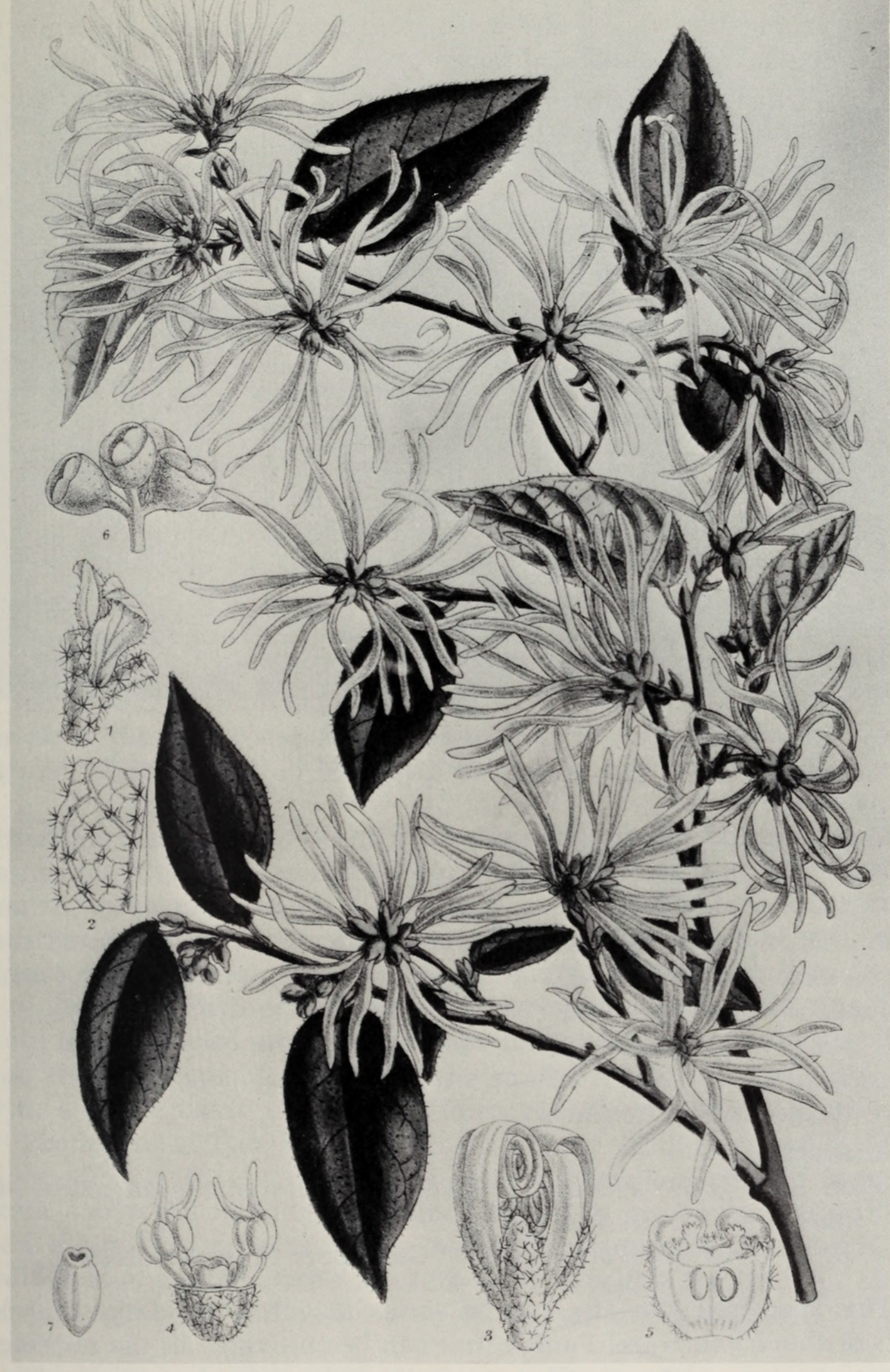

Loropetalum chinense, taken from Curtis Botanical Magazine, vol. 130, plate 7979 . 
mostly in the late winter and early spring, but sporadically throughout the year, Loropetalum chinense would appear to be a most desirable plant for cultivation in the warmer parts of the United States. At present it appears to be grown mostly in California. None of the plants in cultivation is hardy north of Zone 7 , or possibly Zone 6 with protection. The species is native to low elevations in the Khasia Hills of India, throughout much of southern China, and a single locality on the island of Honshu, Japan. It was introduced into cultivation by Charles Maries for the famous nursery of Veitch and Son in 1880 from a collection made in the vicinity of Chiukiang (Kiukiang) in the province of Chianghsi Sheng (Kiangsi), China (Wilson, E. H. 1913. A Naturalist in Western China, vol. 2, p. 3.). For years, all plants in cultivation were evidently grown from this material, and since the original collection site is less than 1000 feet elevation (at Latitude $30^{\circ} \mathrm{N}$., approximately that of Jacksonville, Florida), they were tender even in most parts of England.

The species was generally grown as a tub plant set outside in the summer and wintered in a cool greenhouse where it would produce flowers from Christmas until March. Ernest Wilson wrote a short article for Horticulture (cited above) which outlined the procedure. Wilson also collected the plant in several localities in China, but it is not known whether or not he sent back seeds. At any rate, no plants of Wilson origin ever were displayed on the grounds here in Jamaica Plain.

More recently, plants have appeared in cultivation that are hardy as far north as Washington, D.C. and Baltimore. The original source of this material is not known, but most likely it is Japanese. At any rate, the Japanese plants would be hardier than any known from China or India, and they would show the most promise as the source of plants more amenable to wider culture in the United States.

Loropetalum chinense is available from: Hearn, Mitsch.

\section{Parrotia persica C. A. Mey.}

References:

Hooker, J. B. 1868. Parrotia persica. Curtis Botanical Magazine 94: plate 5744 .

Mey, E. C. 1967. Parrotia persica. Gardeners Chronicle 162 (8): 7.

This species, again alone in its genus, is one of the largest members of the Witch Hazel Family that can be cultivated in the northern United States. Although the species is moderately slow-growing and under certain conditions is almost shrubby in habit, the specimen at the Arnold Arboretum in the Center Street Area is a magnificent tree - perhaps one of the finest specimen plants on the grounds. Started as a cutting from the Harvard Botanical Garden in 1881, it is now 55 feet tall with eight trunks, the largest of which is $31 / 2$ feet in circumference. The total spread is 55 feet. Although they 


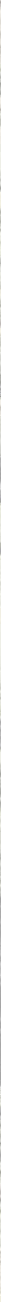

Trunks of the fine specimen of Parrotia persica at the Arnold Arboretum, showing the exfoliating bark. Photo: H. Howard.

can be trained to grow with a single trunk, most cultivated specimens of this species in various parts of the world seem to have this multi-stemmed habit. However, Mr. Roy Lancaster reports that the trees that he observed in their native habitat, which is northern Iran and the Caucasus Mountains of the southern U.S.S.R., usually grow with a single trunk unbranched for a considerable distance.

The leaves of Parrotia persica are strongly reminiscent of those of Hamamelis with an uneven base and shallow but coarse, rounded teeth above the middle; sometimes the teeth are barely discernible, and the margin appears merely wavy. The autumn coloration of the foliage is one of the tree's attractions; it develops the brilliant blend of reds, oranges and yellows so typical of many members of the family.

The flowers are not particularly conspicuous. They appear before the leaves, in late April to early May at the Arnold Arboretum, and are borne in small clusters enclosed by several dark brown, hairy bracts. Petals and sepals are absent, the most conspicuous feature being the numerous, red anthers. Although our specimen rarely blooms profusely, specimens in England have been described as being a haze of red when in full bloom. 




Parrotia persica, taken from Curtis Botanical Magazine, vol. 94, plate 5744. 


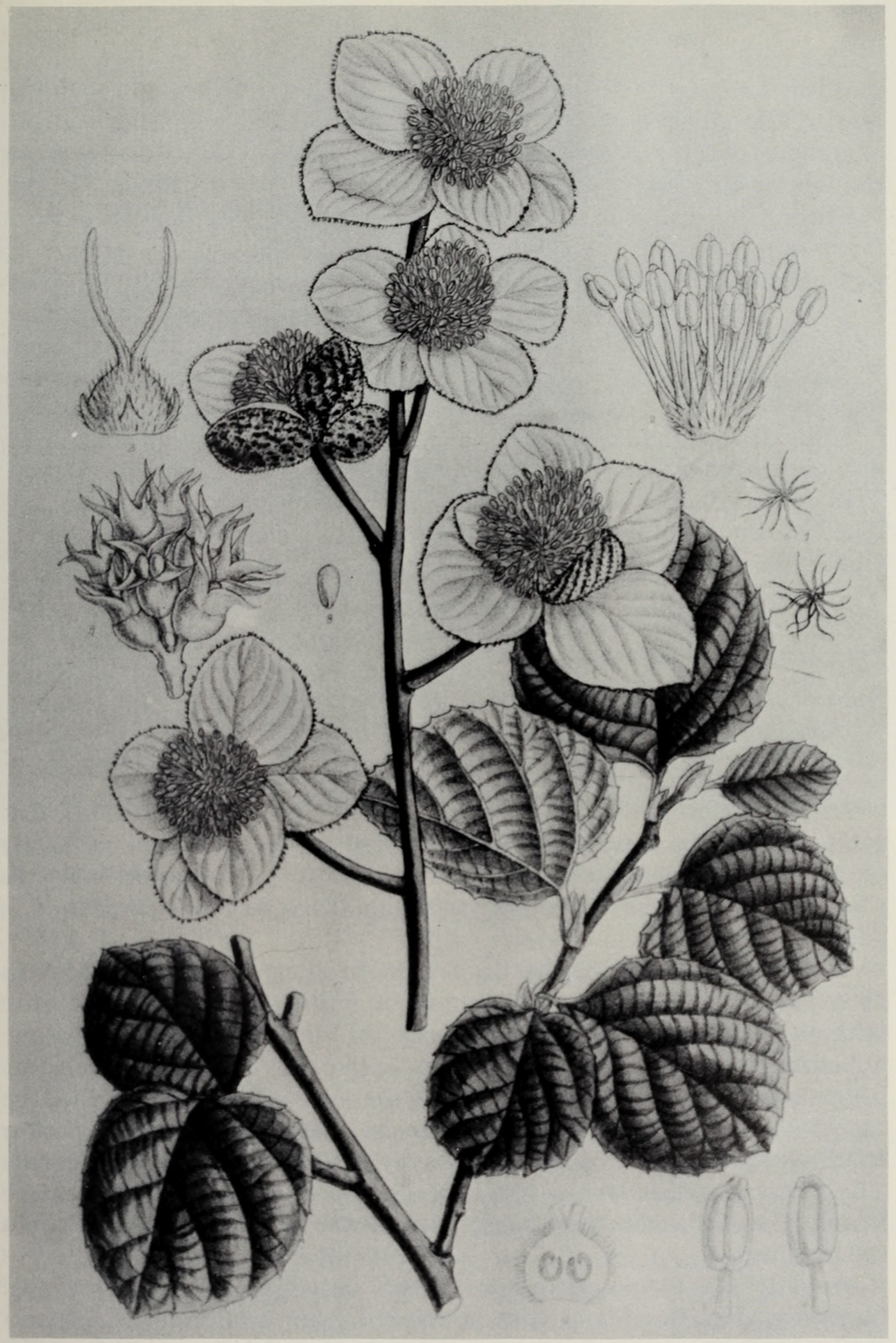

Parrotiopsis jacquemontiana, taken from Curtis Botanical Magazine, vol. 122, plate 7501. 
The bark of the tree and the forms of its trunks are perhaps the most ornamental features of Parrotia. The trunks are slightly ridged and tightly covered with a bark that exfoliates in a mottled pattern of shades of grey. These attributes are particularly effective when the tree is allowed to develop several trunks.

The species was apparently introduced into cultivation in the West from several plants sent from Leningrad (then St. Petersburg) to Kew around 1840. It is rare in cultivation in this country, which is a great shame since a well-grown specimen is magnificent indeed. Perfectly hardy in many parts of the country, it has a rating of Zone 5 , according to Rehder, although it certainly could be grown in parts of Zone 4.

Hilliers' in England lists a form of this species, 'Pendula', with drooping branches, slow growth, and a maximum height of 10 feet. This clone is unavailable in the United States, but the species is listed by the following nurseries: Brimfield, Daubers, Gossler Farms, Hollandia, Hess, Tingle.

\section{Parrotiopsis jacquemontiana (Decne.) Rehd.}

Reference:

Hooker, J. D. 1896. Parrotia jacquemontiana. Curtis Botanical Magazine 122: plate 7501 .

Again a plant little known in cultivation in the United States, this rather handsome species is related to Fothergilla, and was originally described as a member of that genus. It also has been classified as a species of Parrotia, although its resemblance to Parrotia persica is slight indeed.

The flowers appear before the leaves, in late April or early May in New England. They resemble those of Fothergilla in that they are without petals, and they are borne in dense head-like clusters, appearing as tufts of stamens. But unlike Fothergilla, the clusters are surrounded at the base by a series of white bracts, and the assemblage, which may be as much as 2 inches across, is similar to the inflorescence of the Flowering Dogwood (Cornus florida). The plant is attractive in flower, but unlike many members of the Witch Hazel Family, the coloration of the autumn foliage is not spectacular.

Parrotiopsis jacquemontiana is the only species of its genus. Native to the Himalayas and adjacent ranges in India, particularly Kashmir, Pakistan, and Afghanistan, it is locally abundant between 2800 and 9000 feet elevation, forming dense stands. Natives of the area use the tough, flexible twigs in wickerwork and for making rope that is used in the construction of crude suspension bridges. In cultivation in this country it forms a shrub or slender tree to about 20 feet tall. 


\section{Sycopsis sinensis Oliver}

Of the five or so species of Sycopsis, all of them native to the Himalayas and China, this is the only one in cultivation. It is an attractive evergreen shrub, growing to about 8 feet tall in cultivation. The leaves are dull-textured, oval, narrow and pointed, sometimes with a few inconspicuous teeth along the margin. The flowers are somewhat similar to those of Parrotia persica; that is, surrounded by brownish bracts and conspicuous only because of the large reddish anthers. Rehder lists this plant as being hardy in Zone 7, and it does well in Washington, D.C. Plants have never survived here for more than a few years.

Although there are many more attractive broad-leaved evergreens, Sycopsis sinensis is worthy of more frequent cultivation. It is extremely rare in this country, but is offered by Hollandia Gardens.

\section{PROPAGATION}

References:

Bailey, L. H. 1942. The standard cyclopedia of horticulture, ed. 4. Macmillan Co., New York.

Fordham, A. J. 1971. The propagation of Fothergilla. Arnoldia 31: 256-259.

Schopmeyer, C. S., ed. 1974. Seeds of woody plants in the United States. U.S.D.A. Handbook \# 450.

Little has been published on the propagation of the members of the Witch Hazel Family. The seeds of Liquidambar germinate readily after cold stratification for several months, but those of Fothergilla are doubly dormant and must be subjected to warm stratification (optimally for twelve months) followed by cold stratification. It is to be expected that most other members of the family should be treated like Fothergilla. Since the seeds of both Hamamelis and Fothergilla are forcefully ejected from the capsules at maturity, the capsules should be collected just as they are beginning to turn brown.

Layering appears to be an effective means of propagating several genera, particularly if it is done in the spring. Plants of many, such as Fothergilla and Corylopsis, are readily increased by division. Softwood cuttings of Fothergilla root readily, and the other genera are probably similar in this respect, but they have trouble surviving their first winter after transplanting. Therefore, the cutting flats should be moved intact into a cold-storage unit, without disturbing the cuttings, to induce dormancy. 


\section{ADDRESSES OF NURSERY SOURCES}

Boething Treeland Farms

23475 Ventura Boulevard, Woodland Hills, California 91364

Retail

Brimfield Gardens Nursery

245 Brimfield Road, Wethersfield, Connecticut 06109

Retail

Carroll Gardens

East Main Street Ext., Westminster, Maryland 21157

Retail and Wholesale

Central Nursery Company

2675 Johnson Avenue, San Luis Obispo, California 93401

Wholesale

Cole Nursery Company, Inc.

30627 Orr Road, Circleville, Ohio 43113

Wholesale

Dauber's Nurseries

1705 North George Street, Box 1746, York, Pennsylvania 17405

Retail and Wholesale

Forest Nursery Company

Route 2, Box 118-A, McMinnville, Tennessee 37110

Wholesale

Gossler Farms Nursery

1200 Weaver Road, Springfield, Oregon 97477

Retail

Greenbrier Farms Ltd.

412 Thrasher Road, Chesapeake, Virginia 23320

Wholesale

Gulf Stream Nursery, Inc.

Wachapreague, Virginia 23480

Wholesale

Hearn Nurseries

Arcadia, California 91006

Hess Nurseries, Inc.

P.O. Box 326, Route 553, Cedarville, New Jersey 08311

Wholesale

Hollandia Gardens

10725-39th Avenue N.E., Seattle, Washington 98125

Wholesale

Gerard K. Klyn, Inc.

6784 Hopkins Road, Mentor, Ohio 44060

Wholesale

Lake County Nursery Exchange, Inc.

Box 122, Route 84, Perry, Ohio 44081

Wholesale

Light's Landscape Nurserymen

9153 East D Avenue, Richland, Michigan 49083

Retail and Limited Wholesale

Herman Losely \& Son

3410 Shepard Road, Perry, Ohio 44081

Wholesale

Malmo Wholesale Nurseries

14900 Stone Avenue, Seattle, Washington 98133

Wholesale 
Mellinger's, Inc.

2310 West South Range, North Lima, Ohio 44452

Retail

Wholesale

Mitsch Nursery

Route 2, Box 34, Aurora, Oregon 97002

Wholesale

Monrovia Nursery Company

P.O. Box Q, 18331 East Foothill Boulevard, Azusa, California 91702

Wholesale

Panfield Nurseries, Inc.

322 Southdown Road, Huntington, New York 11743

Retail and Wholesale

Peters \& Wilson Nursery

East Millbrae Avenue \& Rollins Road, Millbrae, California 94030

Princeton Nurseries

P.O. Box 191, Princeton, New Jersey 08540

Wholesale

Rosedale Nurseries

Sawmill River Parkway, Hawthorne, New York 10532

Retail

Edward H. Scanlon \& Associates, Inc.

7621 Lewis Road, Olmstead Falls, Ohio 44138

Wholesale

F. W. Schumacher Co., Horticulturists

Sandwich, Massachusetts 02563

Select Nurseries

12831 East Central Avenue, Brea, California 92621

Wholesale

The Tingle Nursery Company

Pittsville, Maryland 21850

Wholesale

West Oregon Nursery

3550 N. W. Saltzman Road, Portland, Oregon 97229

Weston Nurseries

East Main Street, Hopkinton, Massachusetts 01748

Retail and Wholesale 


\section{$2 \mathrm{BHL}$ Biodiversity Heritage Library}

Weaver, Richard E. 1976. "The Witch Hazel Family (Hamamelidaceae)." Arnoldia 36(3), 69-109.

View This Item Online: https://www.biodiversitylibrary.org/item/217505

Permalink: https://www.biodiversitylibrary.org/partpdf/249681

\section{Holding Institution}

Harvard University Botany Libraries

\section{Sponsored by}

BHL-SIL-FEDLINK

\section{Copyright \& Reuse}

Copyright Status: In copyright. Digitized with the permission of the rights holder.

Rights Holder: Arnold Arboretum of Harvard University

License: http://creativecommons.org/licenses/by-nc-sa/4.0/

Rights: https://biodiversitylibrary.org/permissions

This document was created from content at the Biodiversity Heritage Library, the world's largest open access digital library for biodiversity literature and archives. Visit BHL at https://www.biodiversitylibrary.org. 